\title{
Dynamic Spillover Effects in Futures Markets: UK and US Evidence
}

\author{
Nikolaos Antonakakis ${ }^{\mathrm{a}, \mathrm{b}, *}$, Christos Floros ${ }^{\mathrm{c}, \mathrm{d}}$, Renatas Kizys ${ }^{\mathrm{b}}$ \\ ${ }^{a}$ Vienna University of Economics and Business, Department of Economics, Institute for International \\ Economics, Welthandelsplatz 1, 1020, Vienna, Austria. \\ ${ }^{b}$ University of Portsmouth, Economics and Finance Subject Group, Portsmouth Business School, Portland \\ Street, Richmond Building, Portsmouth, PO1 3DE, United Kingdom \\ ${ }^{c}$ Technological Educational Institute of Crete, Department of Accounting and Finance, 71004 Crete, Greece. \\ ${ }^{d}$ Hellenic Open University, School of Social Sciences, Greece.
}

\begin{abstract}
Previous studies on spillover effects in future markets have so far confined themselves to static analyses. In this study, we use a newly introduced spillover index to examine dynamic spillovers between spot and futures market volatility, volume of futures trading and open interest in the UK and the US. Based on a dataset over the period February 25, 2008 to March 14, 2013, that encompasses both the global financial crisis and the Eurozone debt crisis, we find that spot and futures volatilities in the UK (US) are net receivers (net transmitters) of shocks to volume of futures trading and open interest. The analysis also sheds light on the dynamic interdependence of spot and futures market volatilities between the US and the UK. Specifically, the spot and futures volatility spillovers between the UK and US markets are of bidirectional nature, however, they are affected by major economic events such as the global financial and Eurozone debt crisis. Several robustness checks endorse our main findings. Overall, these results have important implications for various market participants and financial sector regulators.
\end{abstract}

Keywords: Spot and Futures Market, Volatility, Volume, Open Interest, Spillovers JEL codes: C32, G11, G12, G15

\section{Introduction}

In the aftermath of the global financial crisis, the appetite for risk in financial markets decreased, as investors sought to rebalance their portfolios towards government bonds and other vehicles of safer investments and to hedge their risky positions in spot markets by

*Corresponding author, phone: +43/1/313 36-4141, fax: +43/1/313 36-90-4141.

Email addresses: nikolaos.antonakakis@wu.ac.at,nikolaos.antonakakis@port.ac.uk (Nikolaos Antonakakis), cfloros@staff.teicrete.gr (Christos Floros), renatas.kizys@port.ac.uk (Renatas Kizys) 
opening the offsetting positions in futures markets. Thus, the importance of futures markets has grown over time and it has stimulated a renewed research interest in the theme. There is a large body of literature that studies various aspects of futures markets. The relation between spot and futures markets is dominated by the price discovery hypothesis (Chan, 1992; Ghosh, 1993) and the volatility spillover hypothesis (Tao and Green, 2012), accompanied by the "heat wave" and the "meteor shower" hypotheses (Wu et al., 2005). The relation among price volatility, volume of trading and open interest gave rise to the sequential arrival of information (SAI) hypothesis (Copeland, 1976) and to the mixture of distributions hypothesis (MDH) (Clark, 1973).

A common feature of the previous empirical studies on the above hypotheses is that they have confined themselves to the examination of static spillover effects (see, for instance, Rittler, 2012; Tao and Green, 2012; Wu et al., 2005; Tse, 1999; Booth et al., 1996; Lin et al., 1994; Hamao et al., 1990, among others). Put differently, previous studies do not investigate the dynamic spillover effects between futures return volatility and trading volume and futures return volatility and open interest. Therefore, previous studies do not consider whether shocks in one market could be attributed to time-varying spillovers within and between US (S\&P 500) and UK (FTSE 100) futures return volatility, trading volume and open interest. This is particularly important as the use of an average measure of spillovers over a fairly long and turbulent period might mask potentially interesting information on secular or cyclical movements in spillover effects. Given that many changes took place over the period 2008-2013, such as the global financial crisis and the Eurozone debt crisis, the transmission mechanism across futures markets needs reconsideration. This study provides new empirical evidence on information transmission in stock index futures markets.

In particular, this study investigates the time-varying linkages between spot, futures, trading volume and open interest in the S\&P 500 and FTSE 100 markets using the Diebold and Yilmaz (2009, 2012) models. The approach proposed by Diebold and Yilmaz (2009, 2012) is (i) particularly suited for the investigation of systems of highly interdependent variables, (ii) it conveniently allows the identification of the main receivers and transmitters of shocks over time and (iii) it takes into account the existing lead-lag relationships among the aforementioned variables. The aim of this study is to test the extent to which the spillover of volatility between futures and spot market is information driven. Put differently, this study examines the dynamic volatility spillover mechanisms and feedback effects between US and UK cash and futures markets within a generalized VAR framework.

This research contributes to the existing literature in four ways. First, we test for dynamic interdependence between spot and futures market volatility, volume of futures trading and open interest in the UK and the US. To the best of our knowledge, trade volume and open interest are not considered in earlier work on volatility spillovers between international stock index futures market (Tao and Green, 2012; Wu et al., 2005). While both volume of futures trading and open interest measure futures-trading activity, they represent different types of traders. In particular, open interest is thought to represent hedging activity, whereas volume of trading is mainly driven by speculative demand for futures (Bessembinder and Seguin, 1993). Building upon Bessembinder and Seguin (1993), this research uses both trade volume and open interest to study the interdependence between spot and 
futures volatility measures. Second, we examine volatility spillover effects in the UK and the US using the recent econometric methods developed by Diebold and Yilmaz (2009, 2012). By means of these methods, both dynamic and static volatility spillovers can be estimated thus extending the study of Rittler (2012). Third, we enrich the state of knowledge about the futures market developments by scrutinizing the period following the global financial crisis. Finally, we evaluate the information content of volume of trading and open interest in forecasting spot and futures return volatilities (Donaldson and Kamstra, 2005; Le and Zurbruegg). Importantly, forecasts of futures volatility can be used for the pricing of futures options.

The empirical findings of this study can be summarized as follows. First, spot and futures volatilities in the UK (the US) are net receivers (net transmitters) of spillovers to volume of futures trading. Second, shocks to volume of futures trading significantly contribute to the forecast error variance of open interest. Third, we find evidence of bidirectional interdependence between spot and futures volatilities in the UK and the US, which is affected by major economic events, such as the global financial crisis and the Eurozone debt crisis. Overall, there is evidence of spillovers within the volatility-volume-open interest relations. These findings are helpful to financial analysts, professional forecasters and risk managers dealing with futures markets, as well as financial sector regulators. For instance, the finding that volume of futures trading has a greater forecasting ability than open interest can be used by professional forecasters to improve the accuracy of their forecasts. Similarly, risk managers might be interested in exploring the information content of international volatility spillovers in forecasting the risk of investment in spot and futures markets. Furthermore, the finding that spot and future volatilities in the UK are net receivers of spillovers from volume of futures trading can raise concerns of the Financial Conduct Authority, a regulator of the financial services industry in the UK. Risk managers (financial analysts) can use the knowledge of futures volume in the UK and of spot and futures market volatility in the US to design optimal hedging strategies against undesired movements (provide a comprehensive analysis of an investment opportunity) in cash and futures markets in the UK.

The rest of this paper is organized as follows. Section 2 present a literature review. Section 3 describes the data used, while Section 4 presents the econometric methodology employed. Section 5 reports the empirical results. Section 6 concludes the paper and discusses points for further research.

\section{Literature Review}

The advent of futures markets opened up new opportunities for traders, investors and researchers. Specifically, researchers find that stock index futures markets incorporate marketwide information more efficiently (Bohl et al., 2011) and more quickly (Brooks et al., 2001; Chou and Chung, 2006; Koutmos and Tucker, 1996; Pizzi et al., 1998; Stoll and Whaley, 1990; Tse, 1999) than spot markets. The issue of information transmission between spot and futures markets is of interest to financial analysts and policy makers. Numerous studies investigate how information from one market is transmitted to another; empirical investigation 
of this issue commonly focuses on the price discovery and volatility spillovers. ${ }^{1}$

Price discovery is the process by which a market (usually the futures market) reflects new information before another related market (usually the spot market), (see, for instance, Sutcliffe, 2006). In general, futures markets play a price discovery role, implying that futures prices contain useful information about cash prices; therefore, arbitrage opportunities exist (Floros and Vougas, 2008). Several studies examine the empirical relationship between the spot and futures markets and provide evidence on the dominant role of futures in the price discovery process (Chan, 1992; Ghosh, 1993). In general, empirical studies find that futures returns lead spot returns (Ng, 1987; Kawaller et al., 1987; Stoll and Whaley, 1990; Floros and Vougas, 2008).

Further, volatility spillover hypothesis exists "if volatility spillovers are combined with asymmetries, a bad news shock in either market may increase volatility and its persistence in both markets" (Tao and Green, 2012). Most articles use GARCH-family models to examine the volatility spillovers between spot and futures markets (see Hamao et al., 1990; Lin et al., 1994; Booth et al., 1996; Tse, 1999; Rittler, 2012). They report spillovers from the futures to the spot market. Wu et al. (2005) examine information transmissions between the S\&P 500 and FTSE 100 index futures and find that the volatility of the US market is affected by the most recent volatility surprise in the UK market. They report no significant lagged spillovers in the conditional mean returns. ${ }^{2}$ Recently, Tao and Green (2012) find significant volatility asymmetries in both the FTSE 100 cash and stock index futures prices. In contrast to the aforementioned articles, Gannon and Choi (1998) and Gannon (2005) use a system of simultaneous equations to identify contemporaneous volatility spillover effects between the Hang Seng stock index spot and futures volatility and the overnight S\&P 500 stock market index futures volatility. In particular, Gannon (2005) documents significant volatility spillover effects from the US to Hong Kong stock index futures market. However, volatility spillover effects are not studied among two important financial variables: trading volume and open interest.

An important aspect of volatility is its relation to liquidity variables, such as trading volume and open interest (see Martinez and Tse, 2008). Trading volume has been widely used as a measure for the rate of information arrival; it is the number of transactions in a futures contract during a specified period of time (see Sutcliffe, 2006). Trading volume is viewed as a proxy for new information, consistent with the sequential information model (Copeland, 1976) and the mixture of distributions hypothesis (Clark, 1973); these theories predict a positive relationship between daily volume and volatility (see, for example, Kawaller et al., 1990; Locke and Sayers, 1993; Kawaller et al., 1994; Wang and Yau, 2000 for US, and Board and Sutcliffe, 1990; Ap Gwilym et al., 1999 for UK). Trading volume measures speculative demand for futures (Lucia and Pardo, 2010). Further, open interest is an important variable

\footnotetext{
${ }^{1}$ Futures markets perform the main functions of risk transfer and price discovery (Silbert, 1985). Further, volatility spillovers between spot and futures markets "play an important role in managing risk for portfolio managers and assessing market stability for policy makers" (Pati and Rajib, 2011) in returns.

${ }^{2}$ Their results support a "heat wave" hypothesis for returns (i.e. information affects one part of the Earth only) and a "meteor shower" hypothesis for volatility (i.e. information arrives on the Earth like a meteor shower) across markets (Wu et al., 2005).
} 
and is regarded as a proxy for dispersion of beliefs (Bessembinder et al., 1996; Mougoué and Aggarwal, 2011); it is an important determinant of volume (Mougoué and Aggarwal, 2011). Open interest is the total number of futures contracts which have not been closed out (i.e. it is equal to the sum of either the outstanding long positions or the sum of the outstanding short positions); see Sutcliffe (2006). According Aguenaou et al. (2011), open interest is an indicator of sentiment in futures markets. It is also used as a proxy for market depth and heterogeneous beliefs (Watanabe, 2001). Floros (2007) argues that knowledge of open interest can prove useful towards the end of major market moves. Further, open interest proxies the demand for futures contracts as hedging instruments (see Lucia and Pardo, 2010; Aguenaou et al., 2011). Open interest is demonstrated to contain information about future economic activity that is not captured by futures prices or net supply-demand imbalances among hedgers in futures markets (Hong and Yogo, 2012). Bessembinder and Seguin (1993) explain that there may be a correlation between open interest and the number of active informed traders; i.e. open interest may be significantly related to trading volume and price volatility. ${ }^{3}$ They argue that "the effect of volume on volatility depends on whether volume generates changes in open interest". Further, Ferris et al. (2002) report that "open interest in the S\&P 500 index futures is a useful proxy for examining the flow of capital into or out of the market, given pricing error information shocks" (Ferris, 2002, p. 371).

\section{Data}

Daily spot and futures returns from the US (S\&P 500) and UK (FTSE 100) are examined. Returns are calculated as the continuously compounded day-to-day capital gain on the stock index. Closing spot and futures prices are obtained from Bloomberg. The sample spans the period from February 25, 2008 to March 14, 2013, and includes 1247 trading days (near-time delivery futures contracts are considered). The standard S\&P 500 (FTSE 100) futures contract size is 250 US dollars (10 Great Britain pounds) per index point of the underlying. In and Kim (2006), in their study on the relation between the S\&P 500 stock index and futures markets, provide details of the S\&P 500 market characteristics. In particular, they argue that the FTSE 100 stock index futures are heavily traded in the last three months before expiration. As a futures contract approaches its expiration, investors close their positions and open new positions in the next near contract. The S\&P 500 and FTSE 100 stock index futures contracts have maturity dates in March, June, September and December and are settled in cash.

Daily spot and futures returns in the US and the UK in conjunction with the total volume of contracts and the open interest in the US and UK futures markets are analyzed. The daily trade volume counts the number of contracts that have been traded on a given day. ${ }^{4}$ The open interest, which measures the size of open positions, equals the number of

\footnotetext{
${ }^{3}$ The authors suggest that greater market depth tends to lower volatility associated with a given volume, implying that a trade that leads to an increase in trading volume and open interest has a smaller effect on volatility than a trade that leads to high volume without a corresponding increase in open interest.

${ }^{4}$ It should be noted that the measure of trade volume does not consider the average size of futures contracts.
} 
outstanding long positions at the end of a day. The descriptive statistics are summarized in Table 1.

[Insert Table 1 about here]

Figures 1 and 2 plot variation over time in the FTSE 100 and S\&P 500 stock index spot and futures prices (Panel A) and returns (Panel B).

[Insert Figures 1 and 2 about here]

Figures 3 and 4 plot variation over time in the FTSE 100 and S\&P 500 stock index futures market volume (Panel A) and open interest (Panel B).

[Insert Figures 3 and 4 about here]

The descriptive statistics are analyzed in more detail in the Appendix.

\section{Empirical Model and Methodology}

In the following, the application of the spillover index approach introduced by Diebold and Yilmaz (2009) is outlined. Building on the seminal work on VAR models by Sims (1980) and the well-known notion of variance decompositions, it allows an assessment of the contributions of shocks to variables to the forecast error variances of both the respective and the other variables of the model. Using rolling-window estimation, the evolution of spillover effects can be traced over time and illustrated by spillover plots.

For the purpose of the present study, the variant of the spillover index in Diebold and Yilmaz (2012) is used, which extends and generalizes the method in Diebold and Yilmaz (2009) in two respects. First, they introduce refined measures of directional spillovers and net spillovers, providing an 'input-output' decomposition of total spillovers into those coming from (or to) a particular source and allowing to identify the main recipients and transmitters of spillovers.

Second, in line with Koop et al. (1996), Pesaran and Shin (1998) and Diebold and Yilmaz (2012), a generalized vector autoregressive framework is employed, in which forecasterror variance decompositions are invariant to the ordering of the variables (in contrast to Cholesky-factor identification used in Debold and Yilmaz, 2009). In the context of the present study, this is particularly important since it is hard if not impossible to justify one particular ordering of the variables on spot and futures volatility. ${ }^{5}$

Indeed, Louhichi (2011) asserts that, while the number of contracts is a good proxy for futures-trading activity, the marginal information content of the average size of futures contract is poor.

${ }^{5}$ We nevertheless explore the robustness of the results against a more structural approach. The discussion is provided in Section 5.4. 
Starting point for the analysis is the following $P$-th order, $K$-variable VAR

$$
y_{t}=\sum_{i=1}^{P} \Theta_{i} y_{t-i}+\varepsilon_{t}
$$

where $y_{t}=\left(y_{1 t}, y_{2 t}, \ldots, y_{K t}\right)$ is a vector of $K$ endogenous variables, $\Theta_{i}, i=1, \ldots, P$, are $K \times K$ parameter matrices and $\varepsilon_{t} \sim(0, \Sigma)$ is vector of disturbances that are independently distributed over time; $t=1, \ldots, T$ is the time index and $k=1, \ldots, K$ is the variable index.

Key to the dynamics of the system is the moving average representation of model 1 , which is given by $y_{t}=\sum_{j=0}^{\infty} A_{j} \varepsilon_{t-j}$, where the $K \times K$ coefficient matrices $A_{j}$ are recursively defined as $A_{j}=\Theta_{1} A_{j-1}+\Theta_{2} A_{j-2}+\ldots+\Theta_{p} A_{j-p}$, where $A_{0}$ is the $K \times K$ identity matrix and $A_{j}=0$ for $j<0$.

Following Diebold and Yilmaz (2012) the generalized VAR framework of Koop et al. (1996) and Pesaran and Shin (1998) is used, which produces variance decompositions invariant to the variable ordering. According to this framework, the $H$-step-ahead forecast error variance decomposition is

$$
\phi_{i j}(H)=\frac{\sigma_{j j}^{-1} \sum_{h=0}^{H-1}\left(e_{i}^{\prime} A_{h} \Sigma e_{j}\right)^{2}}{\sum_{h=0}^{H-1}\left(e_{i}^{\prime} A_{h} \Sigma A_{h}^{\prime} e_{i}\right)},
$$

where $\Sigma$ is the (estimated) variance matrix of the error vector $\varepsilon, \sigma_{j j}$ the (estimated) standard deviation of the error term for the $j$-th equation and $e_{i}$ a selection vector with one as the $i$-th element and zeros otherwise. This yields a $K \times K$ matrix $\phi(H)=\left[\phi_{i j}(H)\right]_{i, j=1, \ldots K}$, where each entry gives the contribution of variable $j$ to the forecast error variance of variable $i$. The main diagonal elements contains the (own) contributions of shocks to the variable $i$ to its own forecast error variance, the off-diagonal elements show the (cross) contributions of the other variables $j$ to the forecast error variance of variable $i$.

Since the own and cross-variable variance contribution shares do not sum to one under the generalized decomposition, i.e., $\sum_{j=1}^{K} \phi_{i j}(H) \neq 1$, each entry of the variance decomposition matrix is normalized by its row sum, such that

$$
\tilde{\phi}_{i j}(H)=\frac{\phi_{i j}(H)}{\sum_{j=1}^{K} \phi_{i j}(H)}
$$

with $\sum_{j=1}^{K} \tilde{\phi}_{i j}(H)=1$ and $\sum_{i, j=1}^{K} \tilde{\phi}_{i j}(H)=K$ by construction.

This ultimately allows to define a total (volatility) spillover index, which is given by

$$
T S(H)=\frac{\sum_{i, j=1, i \neq j}^{K} \tilde{\phi}_{i j}(H)}{\sum_{i, j=1}^{K} \tilde{\phi}_{i j}(H)} \times 100=\frac{\sum_{i, j=1, i \neq j}^{K} \tilde{\phi}_{i j}(H)}{K} \times 100
$$

which gives the average contribution of spillovers from shocks to all (other) variables to the total forecast error variance. 
This approach is quite flexible and allows to obtain a more differentiated picture by considering directional spillovers: Specifically, the directional spillovers received by variable $i$ from all other variables $j$ are defined as

$$
D S_{i \leftarrow j}(H)=\frac{\sum_{j=1, j \neq i}^{K} \tilde{\phi}_{i j}(H)}{\sum_{i, j=1}^{K} \tilde{\phi}_{i j}(H)} \times 100=\frac{\sum_{j=1, j \neq i}^{K} \tilde{\phi}_{i j}(H)}{K} \times 100
$$

and the directional spillovers transmitted by variable $i$ to all other variables $j$ as

$$
D S_{i \rightarrow j}(H)=\frac{\sum_{j=1, j \neq i}^{K} \tilde{\phi}_{j i}(H)}{\sum_{i, j=1}^{K} \tilde{\phi}_{j i}(H)} \times 100=\frac{\sum_{j=1, j \neq i}^{K} \tilde{\phi}_{j i}(H)}{K} \times 100 .
$$

Notice that the set of directional spillovers provides a decomposition of total spillovers into those coming from (or to) a particular source.

By subtracting Equation (5) from Equation (6) the net spillover from variable $i$ to all other variables $j$ are obtained as

$$
N S_{i}(H)=D S_{i \rightarrow j}(H)-D S_{i \leftarrow j}(H),
$$

providing information on whether a country (variable) is a receiver or transmitter of shocks in net terms. Put differently, Equation 7 provides summary information about how much each market contributes to the volatility in other markets, in net terms.

Finally, the net pairwise spillovers can be calculated as

$$
\begin{aligned}
N P S_{i j}(H) & =\left(\frac{\tilde{\phi}_{j i}(H)}{\sum_{i, m=1}^{K} \tilde{\phi}_{i m}(H)}-\frac{\tilde{\phi}_{i j}(H)}{\sum_{j, m=1}^{K} \tilde{\phi}_{j m}(H)}\right) \times 100 \\
& =\left(\frac{\tilde{\phi}_{j i}(H)-\tilde{\phi}_{i j}(H)}{K}\right) \times 100 .
\end{aligned}
$$

The net pairwise volatility spillover between markets $i$ and $j$ is simply the difference between the gross volatility shocks transmitted from market $i$ to market $j$ and those transmitted from $j$ to $i$.

The spillover index approach provides measures of the intensity of interdependence across countries and variables and allows a decomposition of spillover effects by source and recipient.

\section{Empirical findings}

The generalized VAR framework of Diebold and Yilmaz (2012) is used to construct total, directional and net (pairwise) spillovers. The Schwarz Bayesian Information Criterion (BIC) is used to determine the optimal lag length for the VAR models. Moreover, the volatilities of the spot and futures returns of FTSE 100 and S\&P 500 are obtained from the dynamic conditional correlation GARCH (DCC-GARCH) model of Engle (2002). ${ }^{6}$ Section 5.1, presents

\footnotetext{
${ }^{6}$ We employ a four-variate DCC-GARCH model to obtain the conditional variances of spot and futures returns so as to take into account the interdependencies in these two markets' spot and futures returns. However, conditional variances obtained by bivariate DCC-GARCH models in the UK and US do not alter the results.
} 
the estimation results of the bivariate VARs featuring spot and futures return volatility in the US and the UK. Section 5.2 reports the estimation results of the four-variate VARs that allow for international spot and futures return volatility spillovers. Section 5.3 presents the results of the four-variate VARs to study volatility spillovers among spot and futures return volatility, volume of trading and open interest in the UK and the US. Section 5.4 discusses several robustness checks supporting our main findings.

\subsection{Spot-Futures Volatility Spillovers}

Tables 2 and 3, report the decomposition of the total volatility spillover index between futures and spot volatilities in the UK and the US, respectively.

$$
\text { [Insert Tables } 2 \text { and } 3 \text { about here] }
$$

According to Tables 2 and 3, directional spillovers between spot and futures volatilities are around 50\%, suggesting that both volatilities for both the FTSE 100 and S\&P 500 indices are equally informative about the variability in the spot and futures markets. Thus, shocks to futures or spot volatility tend to have similar percentage contributions in both spot and futures markets. This result resonates well with the related literature suggesting that spot and futures markets adjust similarly in response to the same market-wide news. For instance, a standard forward pricing model, used for the pricing of stock index futures contracts, implies that futures and spot returns must have the same variance (Abhyankar, 1995). Chan et al. (1991) report evidence of bilateral dependence between spot and futures volatilities. They argue that "new market information disseminates in both the futures and stock markets and that both markets serve important price discovery roles". Tao and Green (2012) maintain that market-wide news is impounded into the FTSE 100 spot and futures markets simultaneously. Moreover, some news may be associated with futures but not with spot market trading (Antoniou and Holmes, 1995), thus exerting a differential effect on the two markets and explaining why own directional spillover is greater than directional spillover to the other market.

Considering that many changes took place during the years in our sample, 2008-2013, such as the global financial crisis and the Eurozone debt crisis, the use of an average measure of spot and futures volatility spillovers over a fairly long and turbulent period might mask potentially interesting information on secular or cyclical movements in spillover effects. Hence, we estimate the model in Equation (1) using 200-day rolling windows and calculate the forecast error variance decompositions and spillover indices. As a result, time series of estimated spillover indices can be obtained, allowing us to appraise the evolution of total and (net) directional spillovers within and between markets over time.

Figures 5 and 6 , report variation over time in the total, directional and net volatility spillover indices in the UK and the US, respectively.

\section{[Insert Figures 5 and 6 about here]}

Figures 5 and 6 suggest that volatility spillovers experienced significant variation over time. The total spillover index in the UK (US) varies between the values of $44.5 \%(45.8 \%)$ 
and $49.7 \%$ (50\%). Directional spillovers show time-varying patterns in the spot and futures volatility in the UK and the US, and net spillovers tend to switch between positive and negative values in the UK and the US. For instance, the beginning of the sample $(2008 / 2009)$ is marked by the period wherein futures volatility is a net receiver of shocks in the UK and US. This tendency is then reversed several times in the subsequent sample. Altogether, consistent with Abhyankar (1995), there is no any clear-cut evidence which of the two variables - futures or spot volatility - leads spillovers to the other market.

\subsection{Spot-Futures Volatility Spillovers between the UK and US}

Table 4, reports the decomposition of the total volatility spillover index in the volatility of spot and futures returns between the UK and the US. ${ }^{7}$

[Insert Table 4 about here]

Table 4 indicates that the volatility of spot and futures returns in the US spills over to the volatility of spot and futures returns in the UK and vice versa. In particular, the S\&P 500 spot (futures) volatility is responsible for $18.2 \%(18.5 \%)$ and $18.5 \%$ (19\%) of the forecast error variance of the FTSE 100 spot index (futures) volatility, while the FTSE 100 spot index (futures) volatility is responsible for $15.5 \%(17.9 \%)$ and $13.8 \%(16.5 \%)$ of the forecast error variance of the S\&P 500 spot (futures) volatility. This finding suggests that futures investors and traders in both the UK and US markets should monitor developments in both the UK and the US. These results are consistent with Wu et al. (2005) who report evidence of bilateral spillovers between the S\&P 500 and FTSE 100 stock index futures volatility, and with Booth et al. (1997) who find evidence supporting the meteor shower hypothesis in the S\&P 500 and FTSE 100 stock index futures volatility. The results are also partly consistent with Hamao et al. (1990) who find evidence of volatility transmission from S\&P500 to FTSE 100, as such evidence over specific sub-periods is found.

\section{[Insert Figure 7 about here]}

Specifically, Figure 7 which plots the time-varying spillover indices, provides further insights into volatility interdependencies in spot and futures markets between the UK and the US. Notably, the time-varying net volatility spillovers between spot and futures return volatility in the FTSE 100 and in the S\&P 500 stock markets are time- and event-specific. For instance, during the global financial crisis originated in the US, the US market leads the UK market as the net spillovers of spot and futures volatilities are positive (negative) in the US (UK) between the end of 2008 and beginning of 2010, while from the mid of 2010 and until the mid of 2011 - when the debt crisis erupted in the Eurozone - the UK market leads the US market, as the net spillovers of spot and futures returns are negative (positive) in the US (UK). Thus, by employing a time-varying approach more light is shed on time-specific effects of volatility transmission in the spot and futures indices between the UK and the US.

\footnotetext{
${ }^{7} \mathrm{Wu}$ et al. (2005) assert that futures market impounds new information into asset prices faster than the spot market. Kung and Yu (2008) emphasize the leading role of the US spot and futures market in volatility transmission to other developed markets, including UK. We provide evidence on price discovery between the UK and the US markets.
} 


\subsection{Futures Volume and Open Interest Spillovers}

Tables 5 and 6 and Figures 8 and 9 report the results of the analysis of spillovers among spot and futures return volatility, futures volume and open interest in the UK and the US, respectively. ${ }^{8}$

\section{[Insert Table 5 and Figure 8 about here]}

Table 5 suggests that volume of trading in the FTSE 100 futures market explains $51.9 \%$ of the forecast error variance (FEV) of the other variables in the VAR. Volume of trading contributes $33.4 \%$ to the FEV of open interest and it contributes further $9.6 \%$ and $8.9 \%$ to the FEV of spot and futures volatility, respectively. By contrast, only $14.5 \%$ of the FEV of volume of trading is explained by the other variables. This result is further supported by Figure 8, where volume of trading unambiguously appears to be a net transmitter of shocks throughout the sample period. Moreover, Table 5 indicates that futures volatility has been, in general, less important transmitter of shocks than futures volume. Indeed, futures volatility explains $44 \%$ of the FEV of the other variables in the VAR, while accounting only for $1.7 \%$ of the FEV of volume of trading. Consistently with the SAI hypothesis advanced by Copeland (1976), ${ }^{9}$ our findings are indicative of unidirectional spillovers from volume of trading to futures volatility, which is also supported by the negative net pairwise spillovers between futures volatility and futures volume in Figure 8. Thus, volume of trading can significantly contribute to the forecasting ability of spot and futures volatility.

It is evident from Table 5 that the contribution of open interest to the FEV of the other variables is relatively weak. Specifically, open interest accounts for $5.3 \%$ and $5.6 \%$ of the FEV of spot and futures volatility, respectively. It further contributes $10.8 \%$ to the FEV of trading volume. The net spillover of open interest in Figure 8 further indicates that open interest is a net receiver of spillovers from and hence endogenous to the other variables in the VAR. It is worth noting that our results do not disagree with the relevant literature. While information content of open interest is emphasized by the theoretical research (e.g., Hong and Yogo, 2012), empirical analyses have yielded mixed findings. ${ }^{10}$ Instead, Bessembinder and

\footnotetext{
${ }^{8}$ The relation between futures return volatility and volume of trading is extensively investigated in the research that tests for the mixture of distribution hypothesis (MDH) and the sequential arrival of information (SAI) hypothesis (Mougoué and Aggarwal, 2011). Volume of trading (open interest) can be used to measure speculative (hedging) demand in the futures market (Lucia and Pardo, 2010) and to measure futures-trading activity (Bessembinder and Seguin, 1992). Open interest approximates market depth and it provides information about the average informativeness of traders during the day (Bessembinder and Seguin, 1993). Bessembinder and Seguin (1993) use both trading volume and market depth to study price volatility in the futures market.

${ }^{9}$ According to the SAI hypothesis, trading volume, which stems as a proxy of arrival of price-relevant new information, contains significant explanatory power for futures volatility. Information about the number of futures contracts traded in the previous periods may be sequentially used by stock market traders to reduce the riskiness of their positions.

${ }^{10}$ Mougoue and Aggarwal (2011) find that open interest is statistically significant in both the conditional mean and variance equations in foreign exchange futures contracts. In contrast, Hong and Yogo (2012) document that open interest is a statistically insignificant determinant of stock index futures returns.
} 
Seguin (1992) and Chang et al. (2000) assert that open interest is endogenously determined in the futures market. Indeed, as shown in Figure 3 (Panel B), the largest increase in open interest is seen in the beginning of the global financial crisis, when rapidly falling asset prices triggered large increases in hedging demand, as predicted by Chang et al. (2000). In this regard, our results further suggest that an increase in hedging demand does not necessarily trigger a change in spot and futures volatilities or in futures volume.

\section{[Insert Table 6 and Figure 9 about here]}

Table 6 indicates that the S\&P 500 stock index spot and futures volatilities account for $52.9 \%$ and $48.1 \%$, respectively, of the FEV of the other variables in the VAR. Volume of trading accounts for $38.2 \%$ of the FEV. By contrast, open interest contributes $18.5 \%$ to the FEV of the other variables. Conversely, $52.2 \%$ (53.0\%, 38.1\%, $14.4 \%$ of the variability in spot volatility (futures volatility, open interest, trading volume) is captured by the other variables. Taken together, the results imply that, as with the FTSE 100 stock index, volume of trading is a net transmitter of spillovers to the other variables. However, our results for S\&P 500 suggest that the SAI hypothesis is less characteristic to the US stock market than to the UK stock market, insofar as volume of trading explains at best $6 \%$ of the FEV in the S\&P500 spot and futures volatilities, while the spot and futures volatilities capture at best $1.7 \%$ of the FEV of trading volume. Indeed, the examination of net pairwise spillovers between futures volatility and volume of trading indicates that futures volatility generally leads trading volume in the US. These results resonate well with Merrick (1987) who finds that volatility can significantly cause trading volume in the US stock market, but evidence of causality in the opposite direction is weak. Bryant et al. (2006) reject the hypothesis that large speculator and small trader activity, calculated as twice the level of open interest, causes futures volatility. Along similar lines, Chen and Daigler (2008) find that the general public's and institutional traders' volume does not Granger cause futures volatility of the S\&P 500 stock index. Following Xu et al. (2006), the sensitivity of trading volume to lagged return volatility can be explained by microstructure, public information or inventory control effects. ${ }^{11}$

The analysis of pairwise volatility spillover between volume of trading and open interest further suggests that volume of trading is responsible of $26.9 \%$ of the variability in open interest, whereas shocks to open interest contribute $12.0 \%$ to the FEV of trading volume. The information content of trading volume received empirical support in the literature (Telser and Higinbotham, 1977). Figure 9 provides further insights into the relation between spot and futures volatility, trading volume and open interest. As in the UK market, and consistent with the results reported in Table 6, trading volume (open interest) is clearly a net

\footnotetext{
${ }^{11}$ According to Daigler and Wiley (1999), the relation between trading volume and volatility depends upon the type of traders that prevail in the futures market. Specifically, Daigler and Wiley (1999) argue that a positive relation between volume of trading and volatility is driven by the general public who reach decisions based on publicly available information, whereas a negative relation is generated by clearing members, floor traders and other informed traders. In the light of the arguments in Daigler and Wiley (1999), our results imply that a positive relation driven by the general public may be offset by a negative relation driven by informed traders, entailing a zero-sum game effect on futures volatility.
} 
transmitter (receiver) of spillovers throughout the sample period. Spot and futures volatilities tend to transmit spillovers to all other variables in the VAR.

\subsection{Robustness Analysis}

We evaluate the stability of our findings by means of several robustness checks. First, we use the first lag of the FTSE 100 series for the analysis of spot and futures return volatility spillovers between the UK and the US in section 5.2 so as to take into account any bias in our results due to asynchronous trading hours in the US and the UK markets. The exercise corroborates the results obtained using contemporaneous values of the FTSE 100 series in the four-variate VAR. Second, we use alternative $H$-step-ahead forecast error variance decompositions and alternative $m$-day rolling windows. Our results remain qualitatively similar. Third, as an alternative to the generalized vector autoregression framework, in which forecast error variance decompositions are insensitive to the ordering of variables, we also explore the robustness of our results against a more structural approach. To this end, we use Cholesky-factorizations with alternative orderings. The results remain robust. Fourth, we use squared returns of spot and futures returns as an alternative proxy to the DCC-GARCH-type conditional variance. The alternative volatility measure does not appear to influence our main findings. The detailed results are not reported but are available from the authors upon request.

\section{Conclusion}

The goal of this research is to explicitly examine the dynamic interdependence between spot and futures volatility, volume of futures trading and open interest in the UK and the US. In light of the growing interest in trading stock index futures for hedging purposes, it is prerequisite to address the issue of volatility spillover effects between futures returnstrading volume and futures returns-open interest. In this study, the Diebold and Yilmaz (2009, 2012) models are used to study volatility asymmetries in the S\&P 500 and FTSE 100 cash and stock index futures markets, and to investigate further the linkages between spot and futures volatility, trading volume and open interest. In particular, by means of this methodology, the direction and magnitude of volatility spillovers can be identified, and the predictive power of the variables can be measured. Crucially, findings of this research can be used to improve forecasting ability of futures and spot volatilities. ${ }^{12}$

The empirical findings are summarized as follows. First, spot and futures volatilities in the UK (the US) are net receivers (net transmitters) of spillovers to volume of futures trading. This finding also conveys an important message to financial sector regulators. The widely-accepted belief that an increased speculative activity can destabilize financial markets is supported by the results for the UK. On the contrary, for the US, speculative demand for futures tends to endogenously adjust to shocks to spot and futures volatility. Second, shocks to volume of futures trading significantly contribute to the FEV of open

\footnotetext{
${ }^{12}$ A potential drawback of the volatility spillover index of Diebold and Yilmaz $(2009,2012)$ is that it does not identify the sign of volatility spillover effects. However, this issue can be addressed in future research.
} 
interest. Third, evidence of time- and event-specific bidirectional interdependence between spot and futures volatilities in the UK and the US is present. This finding suggests that futures investors and traders in the UK (US) market should monitor developments in the US (UK) market. Overall, it is concluded that there is evidence of spillovers within the volatility-volume-open interest relations. However, the identified spillovers are sensitive to time-specific events such as the global financial crisis and the Eurozone debt crisis. It is thus conjectured that futures investors should consider adjusting their hedging strategies according to key economic events in specific markets and regions so as to minimize risk associated with spot and futures trading.

Liquidity and market depth is reflected in the sizes of trading volume (liquidity) and open interest (depth), that may play an important role in pricing efficiency and hedging. The price-trading volume, or open interest relation, is important for several reasons, i.e. it provides insights as to the structure of markets (such as the presence of hedging and arbitrage activities). The empirical findings of this study have practical implications for traders and futures markets participants. For example, the causal relationship between futures volatility and trading volume reported in this study implies that knowledge of current trading volume improves the ability to forecast futures prices. This may lead to the construction of more accurate hedge ratios and improvements in investment strategies (Mougoué and Aggarwal, 2011). This is not the case for open interest, which means that the flow of money into the futures market is not so important, as it is the trading volume which measures the pressure or intensity behind a price up or down trend (Sari et al., 2012). We argue that market liquidity dominates market depth, in most cases; this is highly important for traders and investors of these markets.

Further research may (i) examine the volatility spillover effects in commodities markets, (ii) explore other explanatory variables that might influence this dynamic interdependence, and (iii) consider another method (Regime-Switching MGARCH or asymmetric volatility spillovers as in Baruník et al. (2013)) to compare the results with those reported from the Diebold and Yilmaz models estimated in this study.

\section{Acknowledgments}

We would like to thank Brian M. Lucey (Editor), two anonymous reviewers and the participants of the 12th INFINITI Conference on International Finance for their valuable comments and suggestions on a previous draft of this paper. The usual disclaimer applies.

\section{References}

Abhyankar, A. H., (1995). Return and volatility dynamics in the FTSE-100 stock index and stock index futures markets. Journal of Futures Markets 15 (4), 457-488.

Aguenaou, S., Ap Gwilym, O. \& Rhodes, M., (2011). Open interest, cross listing, and information shocks. Journal of Futures Markets 31 (8), 755-778. 
Antoniou, Antonios \& Holmes, P., (1995). Futures trading, information and spot price volatility: Evidence for the FTSE-100 stock index futures contract using GARCH. Journal of Banking \& Finance 19 (1), 117-129.

Ap Gwilym, O., McMillan, David \& Speight, A., (1999). The intraday relationship between volume and volatility in LIFFE futures markets. Applied Financial Economics 9 (6), 593604.

Baruník, J., Kočenda, Evžen \& Vácha, L., (2013). Asymmetric volatility spillovers: revisiting the Diebold-Yilmaz (2009) spillover index with realized semivariance. Tech. rep., Mimeo.

Bessembinder, H., Chan, Kalok \& Seguin, P. J., (1996). An empirical examination of information, differences of opinion, and trading activity. Journal of Financial Economics 40 (1), 105-134.

Bessembinder, H. \& Seguin, P., (1992). Futures trading activity and stock price volatility. Journal of Finance 47 (5), 2015-2034.

Bessembinder, H. \& Seguin, P., (1993). Price volatility, trading volume, and market depth: Evidence from futures markets. Journal of Financial and Quantitative Analysis 28 (1), 21-39.

Board, J. L. G. \& Sutcliffe, C. M. S., (1990). Information, volatility, volume and maturity: An investigation of stock index futures. Review of Futures Markets 9 (3), 532-549.

Bohl, M. T., Salm, Christian A. \& Schuppli, M., (2011). Price discovery and investor structure in stock index futures. Journal of Futures Markets 31 (3), 282-306.

Booth, G., Chowdhury, M., Martikainen, T. \& Tse, Y., (1997). Intraday volatility in international stock index futures markets: Meteor showers or heat waves? Management Science 43 (11), 1564-1576.

Booth, G. G., Lee, T. \& Tse, Y., (1996). International linkages in Nikkei stock index futures markets. Pacific Basin Finance Journal 4 (1), 59-76.

Brooks, C., Rew, Alistair G. \& Ritson, S., (2001). A trading strategy based on the leadlag relationship between the spot index and futures contract for the FTSE100. International Journal of Forecasting 17 (1), 31-44.

Bryant, H., Bessler, D.A. \& Haigh, M., (2006). Causality in futures markets. Journal of Futures Markets 26 (1), 1039-1057.

Chan, K., (1992). A further analysis of the leadlag relationship between the cash market and stock index futures market. Review of Financial Studies 5 (1), 123-152.

Chan, K., Chan, K.C. \& Karolyi, G., (1991). Intraday volatility in the stock index and stock index futures markets. Review of Financial Studies 4 (4), 657-684.

Chang, E., Chou, R.Y. \& Nelling, E., (2000). Market volatility and the demand for hedging in stock index futures. Journal of Futures Markets 20 (2), 105-125.

Chen, Z. \& Daigler, R., (2008). An examination of the complementary volume-volatility information theories. Journal of Futures Markets 28 (10), 963-992. 
Chou, Robin K. \& Chung, H., (2006). Decimalization, trading costs, and information transmission between ETFs and index futures. Journal of Futures Markets 26 (2), 131-151.

Clark, P., (1973. A subordinated stochastic process model with finite variance for speculative prices. Econometrica 41 (1), 135-155.

Copeland, T., (1976). A model of asset trading under the assumption of sequential information arrival. Journal of Finance 31 (1), 1149-1168.

Daigler, R.T. \& Wiley, M., (1999). The impact of trader type on the futures volatilityvolume relation. Journal of Finance 54 (6), 2297-2316.

Diebold, Francis X. \& Yilmaz, K., (2009). Measuring financial asset return and volatility spillovers, with application to global equity markets. Economic Journal 119 (534), 158-171. Diebold, Francis X. \& Yilmaz, K., (2012). Better to give than to receive: Predictive directional measurement of volatility spillovers. International Journal of Forecasting 28 (1), 57-66.

Donaldson, R.G. \& Kamstra, M., (2005). Volatility forecasts, trading volume, and the ARCH versus option- implied volatility trade-off. Journal of Financial Research 28 (4), 519-538.

Engle, R., (2002). Dynamic conditional correlation: A simple class of multivariate generalized autoregressive conditional heteroskedasticity models. Journal of Business \& Economic Statistics 20 (3), 339-350.

Ferris, S. P., Park, Hun Y. \& Park, K., (2002). Volatility, open interest, volume, and arbitrage: evidence from the S\&P 500 futures market. Applied Economics Letters 9 (6), 369-372.

Floros, C., (2007). Price and open interest in Greek stock index futures market. Journal of Emerging Market Finance 6 (2), 191-202.

Floros, C. \& Vougas, D. V., (2008). The efficiency of Greek stock index futures market. Managerial Finance 34 (7), 498-519.

Gannon, G.L. \& Choi, D., (1998). Structural models: Intra/inter-day volatility transmission and spillover persistence of the HSI, HSIF and S\&P 500 futures. International Review of Financial Analysis 7 (1), 19-38.

Gannon, G., (2005). Simultaneous volatility transmissions and spillover effects U.S. and Hong Kong stock and futures markets. International Review of Financial Analysis 14 (3), 326-336.

Ghosh, A., (1993). Cointegration and error correction models: Intertemporal causality between index and futures prices. Journal of Futures Markets 13 (2), 193-198.

Hamao, Y., Masulis, R.W. \& Ng, V., (1990). Correlations in price changes and volatility across international stock markets. Review of Financial Studies 3 (2), 281-307.

Hong, Harrison \& Yogo, M., (2012). What does futures market interest tell us about the macroeconomy and asset prices? Journal of Financial Economics 105 (3), 473-490.

Kawaller, I. G., Koch, Paul D. \& Peterson, J. E., (1994). Assessing the intraday relationship between implied and historical volatility. Journal of Futures Markets 14 (3), 323-346. 
Kawaller, I. G., Koch, Paul D. \& Koch, T. W., (1987). The temporal price relationship between S\&P 500 futures and the S\&P 500 index. The Journal of Finance 42 (5), 13091329.

Kawaller, I. G., Koch, Paul D. \& Koch, T. W., (1990). Intraday relationships between volatility in S\&P 500 futures prices and volatility in the S\&P 500 index. Journal of Banking E Finance 14 (23), 373-397.

Kim, F. I. . S., (2006). The hedge ratio and the empirical relationship between the stock and futures markets: A new approach using wavelet analysis. Journal of Business 79 (2), 799-820.

Koop, G., Pesaran, M. Hashem \& Potter, S. M., (1996). Impulse response analysis in nonlinear multivariate models. Journal of Econometrics 74 (1), 119-147.

Koutmos, Gregory \& Tucker, M., (1996). Temporal relationships and dynamic interactions between spot and futures stock markets. Journal of Futures Markets 16 (1), 55-69.

Kung, Ling-Ming \& Yu, S.-W., (2008). Prediction of index futures returns and the analysis of financial spillovers: A comparison between GARCH and the Grey theorem. European Journal of Operational Research 186 (3), 1184-1200.

Le, V. \& Zurbruegg, R., (2010). The role of trading volume in volatility forecasting. Journal of International Financial Markets, Institutions and Money 20 (5), 533-555.

Lien, Donald \& Tse, Y. K., (2002). Some recent developments in futures hedging. Journal of Economic Surveys 16 (3), 357-396.

Lin, W. L., Engle, R. F. \& Ito, T., (1994). Do bulls and bears move across borders? International transmission of stock teturns and Volatility. Review of Financial Studies 7 (3), 507-538.

Locke, P.R. \& Sayers, C., (1993). Intra-day futures price volatility: Information effects and variance persistence. Journal of Applied Econometrics 8 (1), 15-30.

Louhichi, W., (2011). What drives the volume-volatility relationship on Euronext Paris? International Review of Financial Analysis 20 (4), 200-206.

Lucia, Julio J. \& Pardo, A., (2010). On measuring speculative and hedging activities in futures markets from volume and open interest data. Applied Economics 42 (12), 15491557 .

Martinez, Valeria \& Tse, Y., (2008). Intraday volatility in the bond, foreign exchange, and stock index futures markets. Journal of Futures Markets 28 (4), 313-334.

Merrick, J., (1987). Volume determination in stock index futures markets: An analysis of arbitrage and volatility effects. Journal of Futures Markets 7 (5), 483-496.

Mougoué, Mbodja \& Aggarwal, R., (2011). Trading volume and exchange rate volatility: Evidence for the sequential arrival of information hypothesis. Journal of Banking \& Finance 35 (10), 2690-2703.

$\mathrm{Ng}, \mathrm{N} .,(1987)$. Detecting spot prices forecasts in futures prices using causality tests. Review of Futures Markets 6 (1), 61-89. 
Pati, Pratap Chandra \& Rajib, P., (2011). Intraday return dynamics and volatility spillovers between NSE S\&P CNX Nifty stock index and stock index futures. Applied Economics Letters 18 (6), 567-574.

Pesaran, H. Hashem \& Shin, Y., (1998). Generalized impulse response analysis in linear multivariate models. Economics Letters 58 (1), 17-29.

Pizzi, M. A., Economopoulos, Andrew J. \& O’Neill, H. M., (1998). An examination of the relationship between stock index cash and futures markets: A cointegration approach. Journal of Futures Markets 18 (3), 297-305.

Rittler, D., (2012). Price discovery and volatility spillovers in the European Union emissions trading scheme: A high-frequency analysis. Journal of Banking $\&$ Finance 36 (3), 774-785. Sari, R., Hammoudeh, S., Chang, Chia-Lin \& McAleer, M., (2012). Causality between market liquidity and depth for energy and grains. Energy Economics 34 (5), 1683-1629.

Silber, W., (1985). The economic role of financial futures. In A. E. Peck (Ed.), Futures markets: their economic role. Washington, DC: American Enterprise Institute for Public Policy Research.

Sims, C., (1980). Macroeconomics and reality. Econometrica 48, 1-48.

Stoll, Hans R. \& Whaley, R. E., (1990). The dynamics of stock index and stock index futures returns. Journal of Financial and Quantitative Analysis 25 (04), 441-468.

Sutcliffe, C., (2006). Stock index futures (3rd Ed.). Ashgate Publishing.

Tao, Juan \& Green, C. J., (2012). Asymmetries, causality and correlation between FTSE100 spot and futures: A DCC-TGARCH-M analysis. International Review of Financial Analysis 24 (C), 26-37.

Telser, L.G. \& Higinbotham, H., (1977). Organized futures markets: Costs and benefits. Journal of Political Economy 85 (5), 969-1000.

Tse, Y., (1999). Price discovery and volatility spillovers in the DJIA index and futures markets. Journal of Futures Markets 19 (8), 911-930.

Wang, George H. K. \& Yau, J., (2000). Trading volume, bid-ask spread, and price volatility in futures markets. Journal of Futures Markets 20 (10), 943-970.

Watanabe, T., (2001). Price volatility, trading volume, and market depth: Evidence from the Japanese stock index futures market. Applied Financial Economics 11 (6), 651-658.

Wu, C., Li, J. \& Zhang, W., (2005). Intradaily periodicity and volatility spillovers between international stock index futures markets. Journal of Futures Markets 25 (6), 553-585.

$\mathrm{Xu}, \mathrm{X}$. , Chen, P. \& Wu, C., (2006). Time and dynamic volume-volatility relation. Journal of Banking $\& 5$ Finance 30 (5), 1535-1558. 


\section{Figures}

Figure 1: FTSE 100 - Spot \& Futures Prices and Returns

Panel A - FTSE 100 Stock Index Spot and Futures Prices
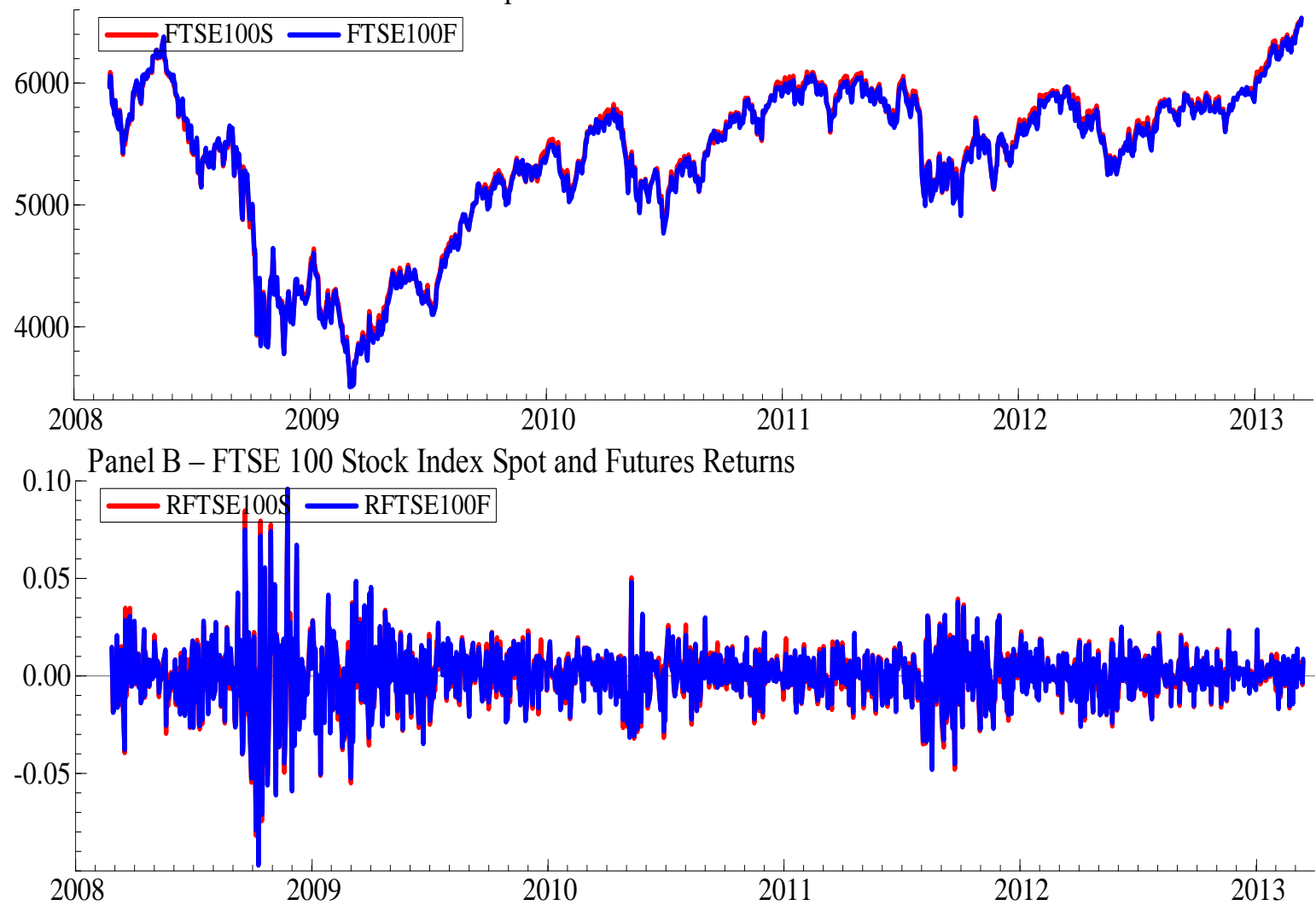

Note: This figure plots variation over time in the FTSE 100 stock index spot and futures prices (Panel A) and returns (Panel B). The sample period is 02/25/2008 - 04/23/2013 (a total of 1247 observations). 
Figure 2: S\&P 500 - Spot \& Futures Prices and Returns

Panel A - S\&P 500 Stock Index Spot and Futures Prices
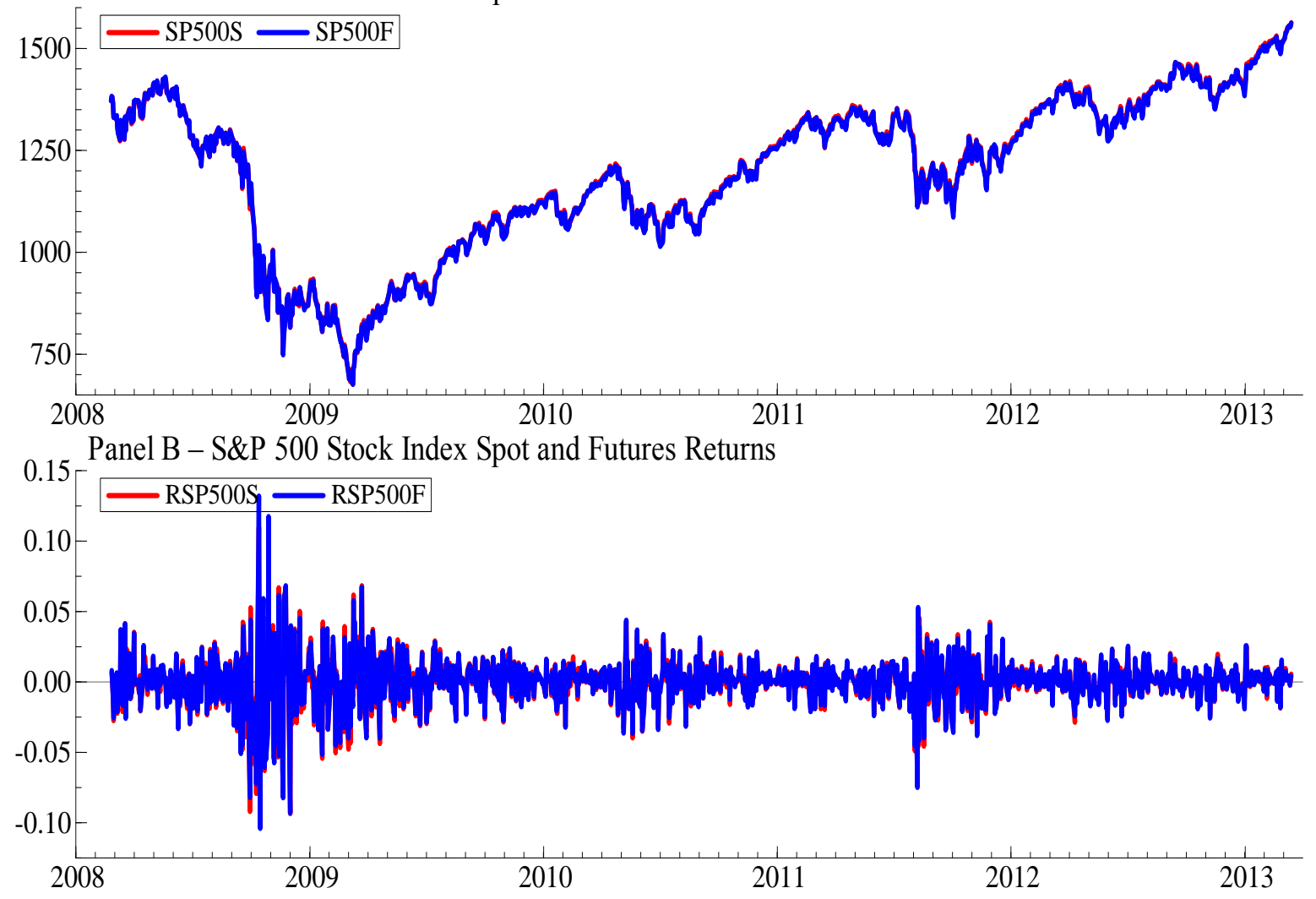

Note: This figure plots variation over time in the S\&P 500 stock index spot and futures prices (Panel A) and returns (Panel B). The sample period is 02/25/2008 - 04/23/2013 (a total of 1247 observations). 
Figure 3: FTSE 100 - Trading Volume \& Open Interest
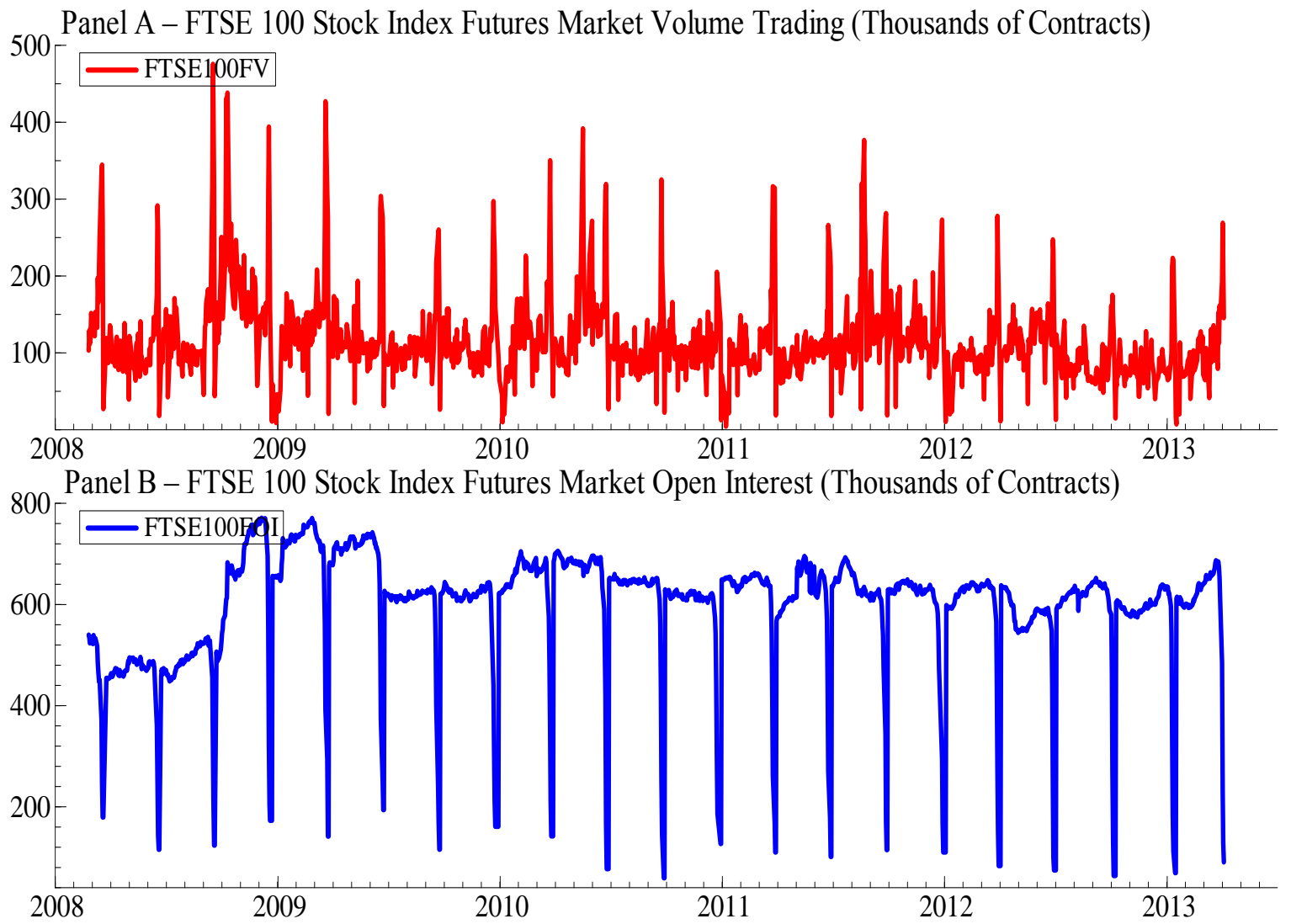

Note: This figure plots variation over time in the FTSE 100 stock index futures market trading volume (Panel A) and open interest (Panel B), in thousands of contracts. The sample period is $02 / 25 / 2008$ 04/23/2013 (a total of 1247 observations). 
Figure 4: S\&P 500 - Trading Volume \& Open Interest

Panel A - S\&P 500 Stock Index Futures Market Volume Trading (Thousands of Contracts)

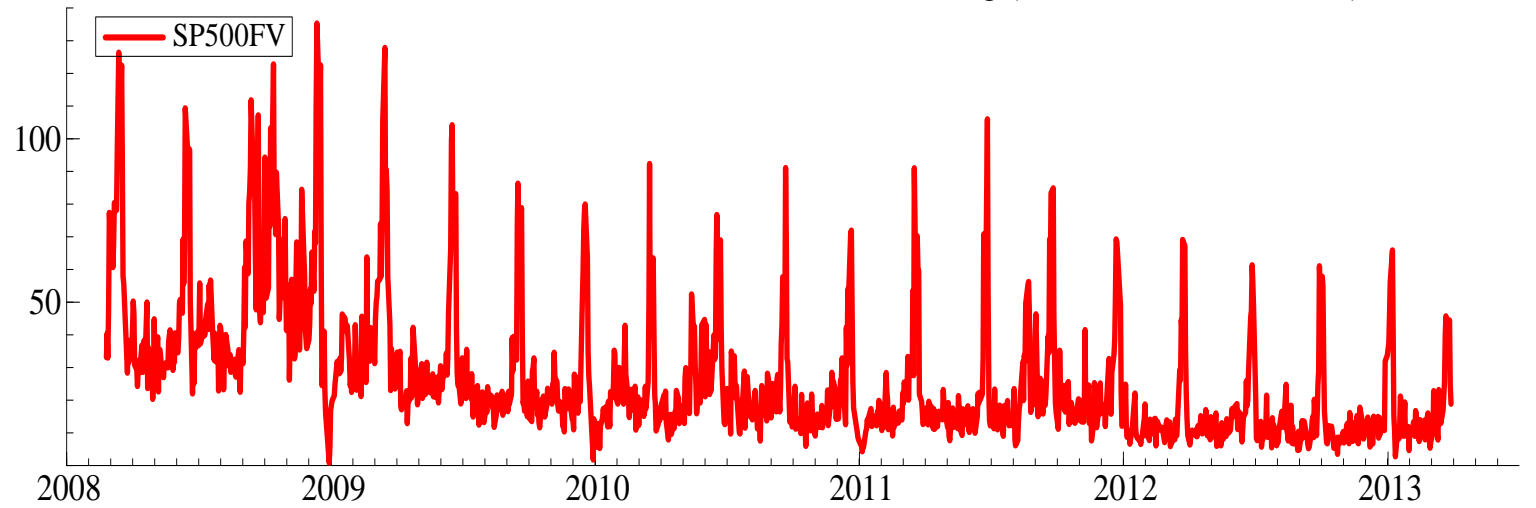

Panel B - S\&P 500 Stock Index Futures Market Open Interest (Thousands of Contracts)

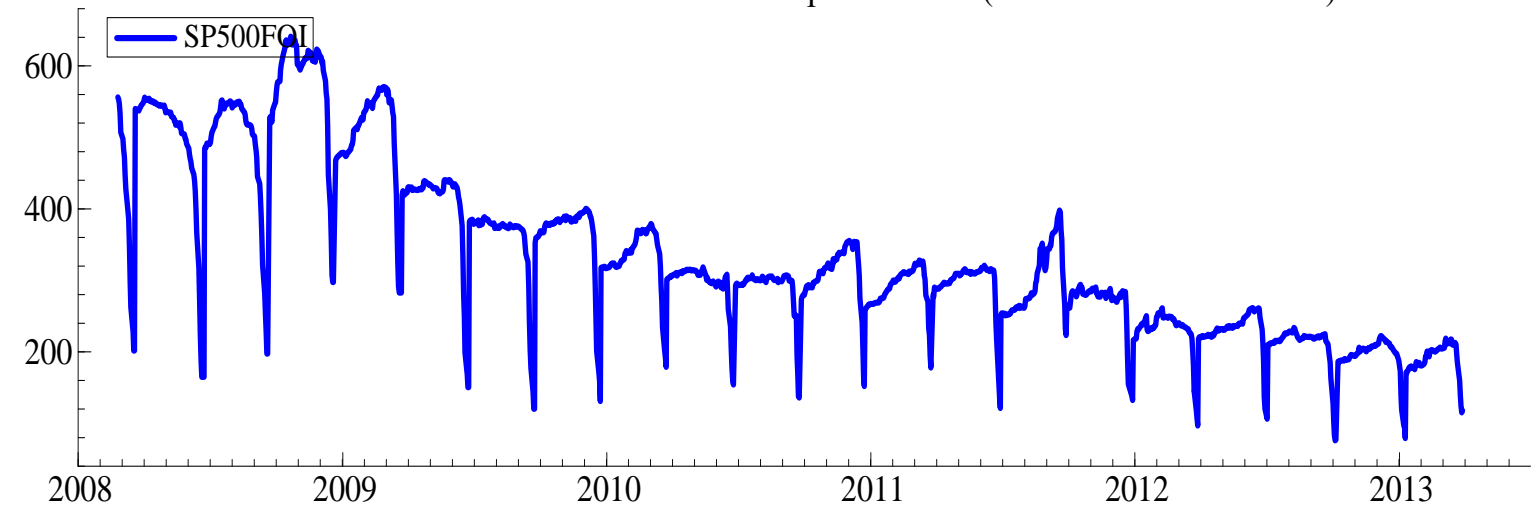

Note: This figure plots variation over time in the S\&P 500 stock index futures market trading volume (Panel A) and open interest (Panel B), in thousands of contracts. The sample period is $02 / 25 / 2008-04 / 23 / 2013$ (a total of 1247 observations). 
Figure 5: Total, Directional and Net Spillover Indices - FTSE 100 Spot and Futures Volatility
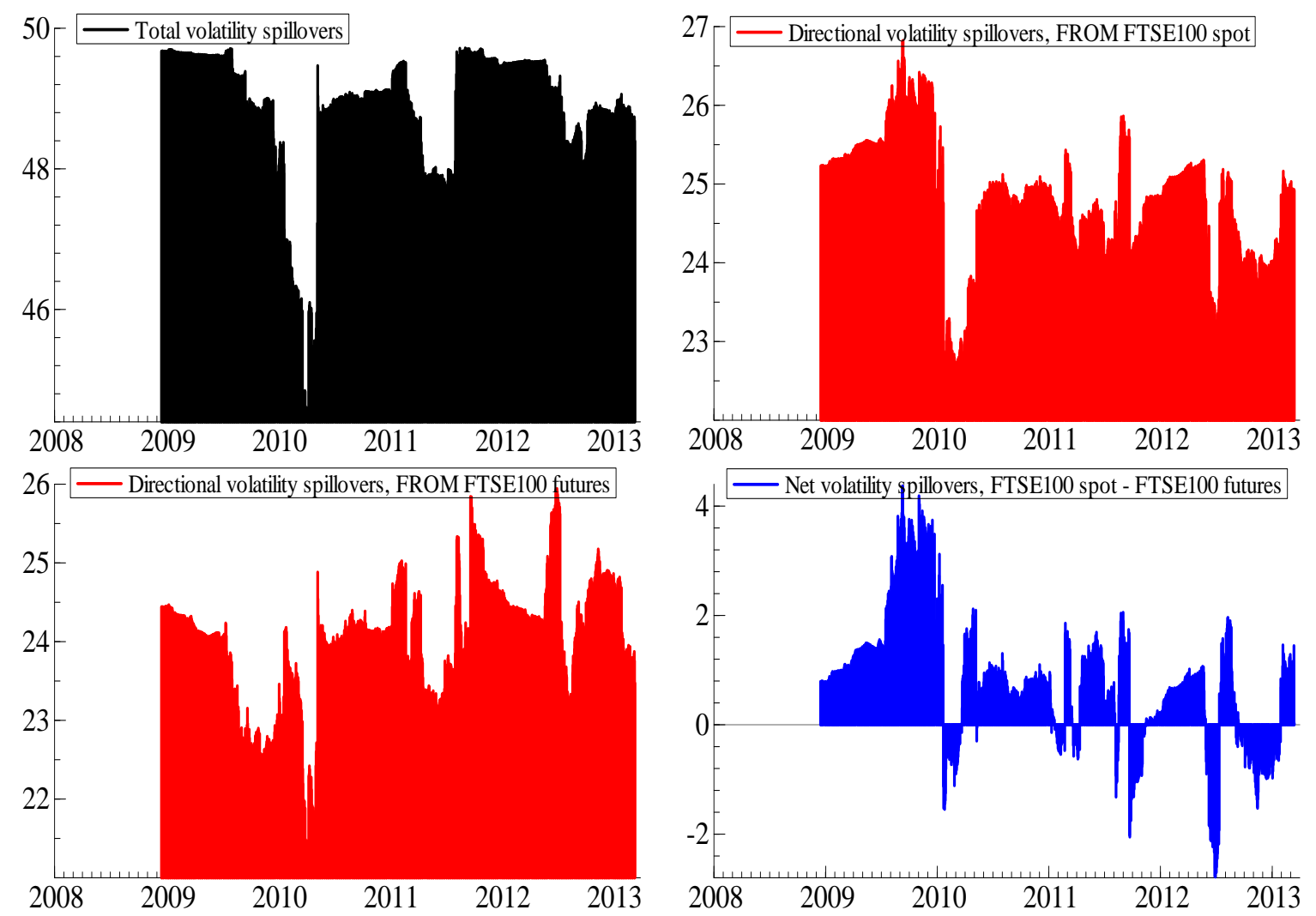

Note: Dynamic total, directional and net spillover indices are depicted in this figure. Positive (negative) values of the net spillover index indicate that the FTSE 100 spot volatility is a net transmitter (receiver) and the FTSE 100 futures volatility is a net receiver (transmitter) of spillovers. The underlying variance decomposition is based upon a bivariate VAR of order 5, which is dictated by the Schwarz Bayesian Information Criterion. Spot and futures volatilities are measured by the conditional variances that are obtained from the DCC-GARCH model of Engle (2002). Spillover indices are estimated using 200-day rolling windows. Spillover indices, given by Equations 4-8, are calculated from variance decompositions based on 10-stepahead forecasts. We use daily data for the period 02/25/2008 - 04/23/2013 (a total of 1247 observations). 
Figure 6: Total, Directional and Net Spillover Indices - S\&P 500 Spot and Futures Volatility
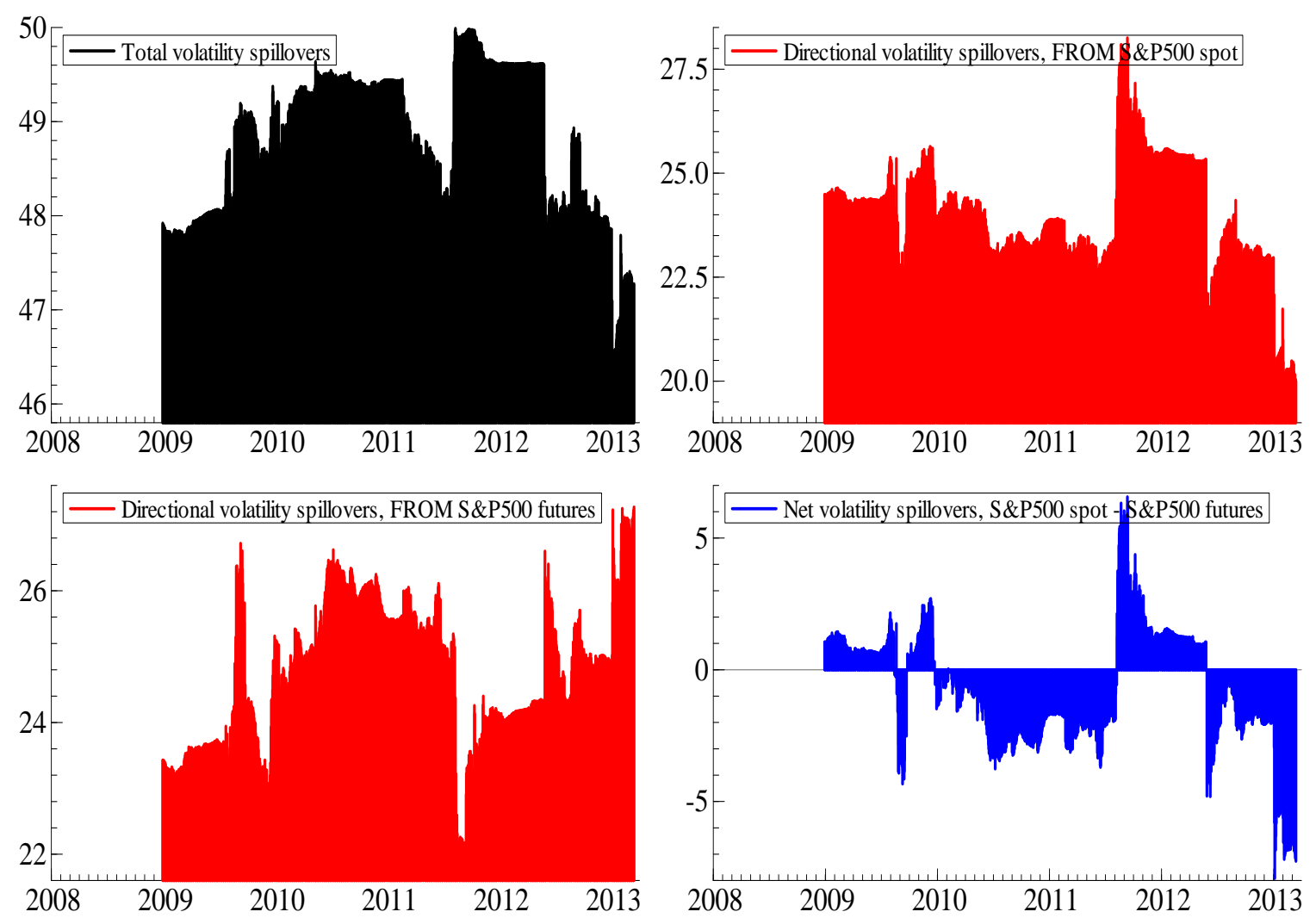

Note: Dynamic total, directional, net spillover indices are depicted in this figure. Positive (negative) values of the net spillover index indicate that the S\&P 500 spot volatility is a net transmitter (receiver) and the S\&P 500 futures volatility is a net receiver (transmitter) of spillovers. The underlying variance decomposition is based upon a bivariate VAR of order 12, which is dictated by the Schwarz Bayesian Information Criterion. Spot and futures volatilities are measured by the conditional variances that are obtained from the DCCGARCH model of Engle (2002). Spillover indices are estimated using 200-day rolling windows. Spillover indices, given by Equations 4-8 are calculated from variance decompositions based on 10-step-ahead forecasts. We use daily data for the period 02/25/2008 - 04/23/2013 (a total of 1247 observations). 
Figure 7: Total, Directional and Net Spillover Indices - FTSE 100 \& S\&P500 Spot and Futures Volatility
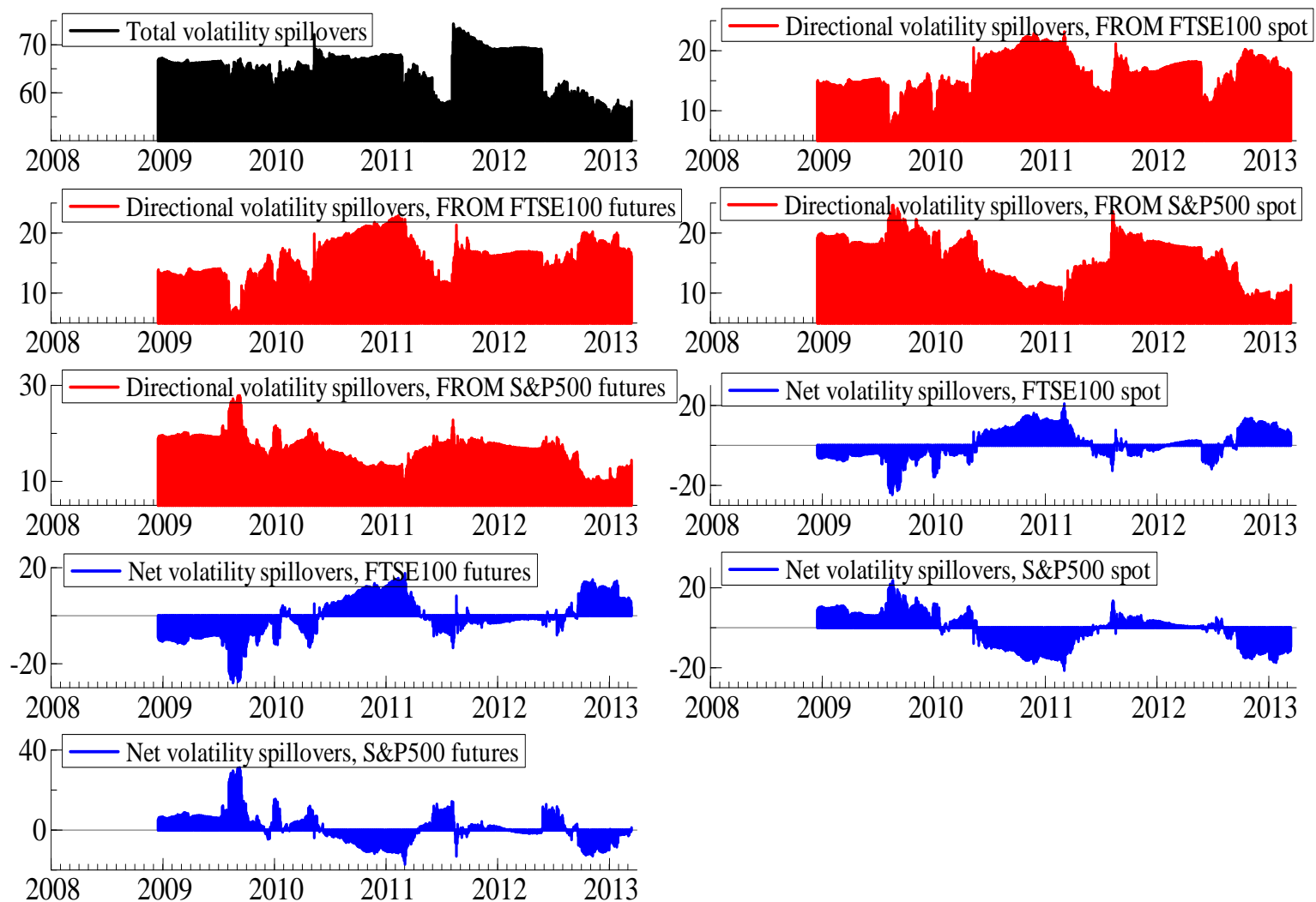

Note: Dynamic total, directional, net spillover indices are depicted in this figure. For instance, positive (negative) values of the FTSE 100 futures net spillover indicate that the FTSE 100 futures volatility is a net transmitter (receiver) and the other volatility measures are net receivers (transmitters) of spillovers. The underlying variance decomposition is based upon a bivariate VAR of order 12, which is dictated by the Schwarz Bayesian Information Criterion. Spot and futures volatilities are measured by the conditional variances that are obtained from the DCC-GARCH model of Engle (2002). Spillover indices are estimated using 200-day rolling windows. Spillover indices, given by Equations 4-8, are calculated from variance decompositions based on 10-step-ahead forecasts. We use daily data for the period 02/25/2008 - 04/23/2013 (a total of 1247 observations). 
Figure 8: Total, Directional and Net Spillover Indices - FTSE 100 Spot \& Futures Volatility, Futures Volume and Open Interest
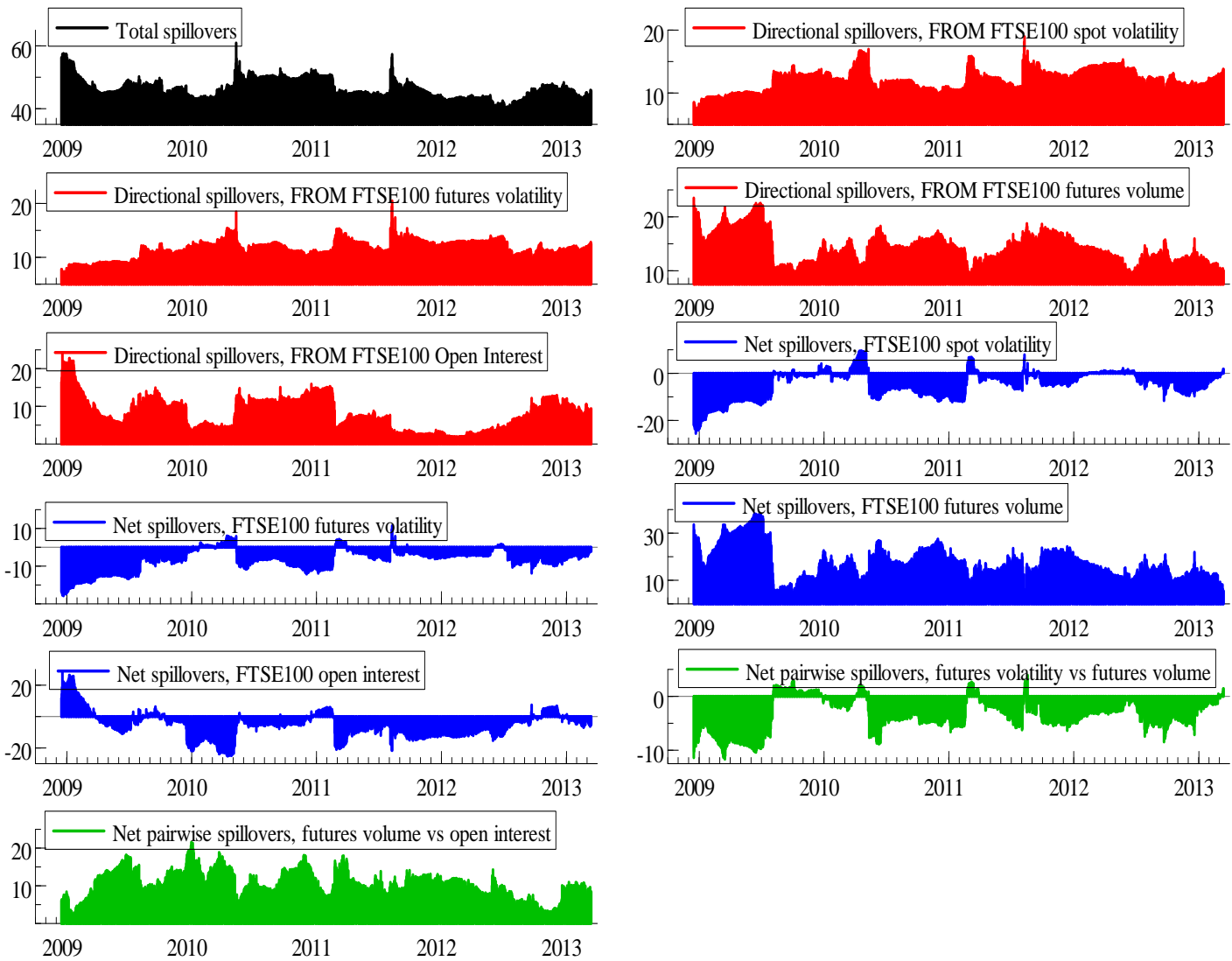

Note: Dynamic total, directional, net spillover and net pairwise spillover indices are depicted in this figure. For instance, positive (negative) values of the FTSE 100 futures volume net spillover indicate that the FTSE 100 futures volume is a net transmitter (receiver) whereas the FTSE 100 futures and spot volatility, and the open interest are collectively net receivers (transmitters) of spillovers. The underlying variance decomposition is based upon a bivariate VAR of order 5, which is dictated by the Schwarz Bayesian Information Criterion. Spot and futures volatilities are measured by the conditional variances that are obtained from the DCC-GARCH model of Engle (2002). Spillover indices are estimated using 200-day rolling windows. Spillover indices, given by Equations 4-8, are calculated from variance decompositions based on 10-stepahead forecasts. We use daily data for the period 02/25/2008 - 04/23/2013 (a total of 1247 observations). 
Figure 9: Total, Directional and Net Spillover Indices - S\&P 500 Spot \& Futures Volatility, Futures Volume and Open Interest
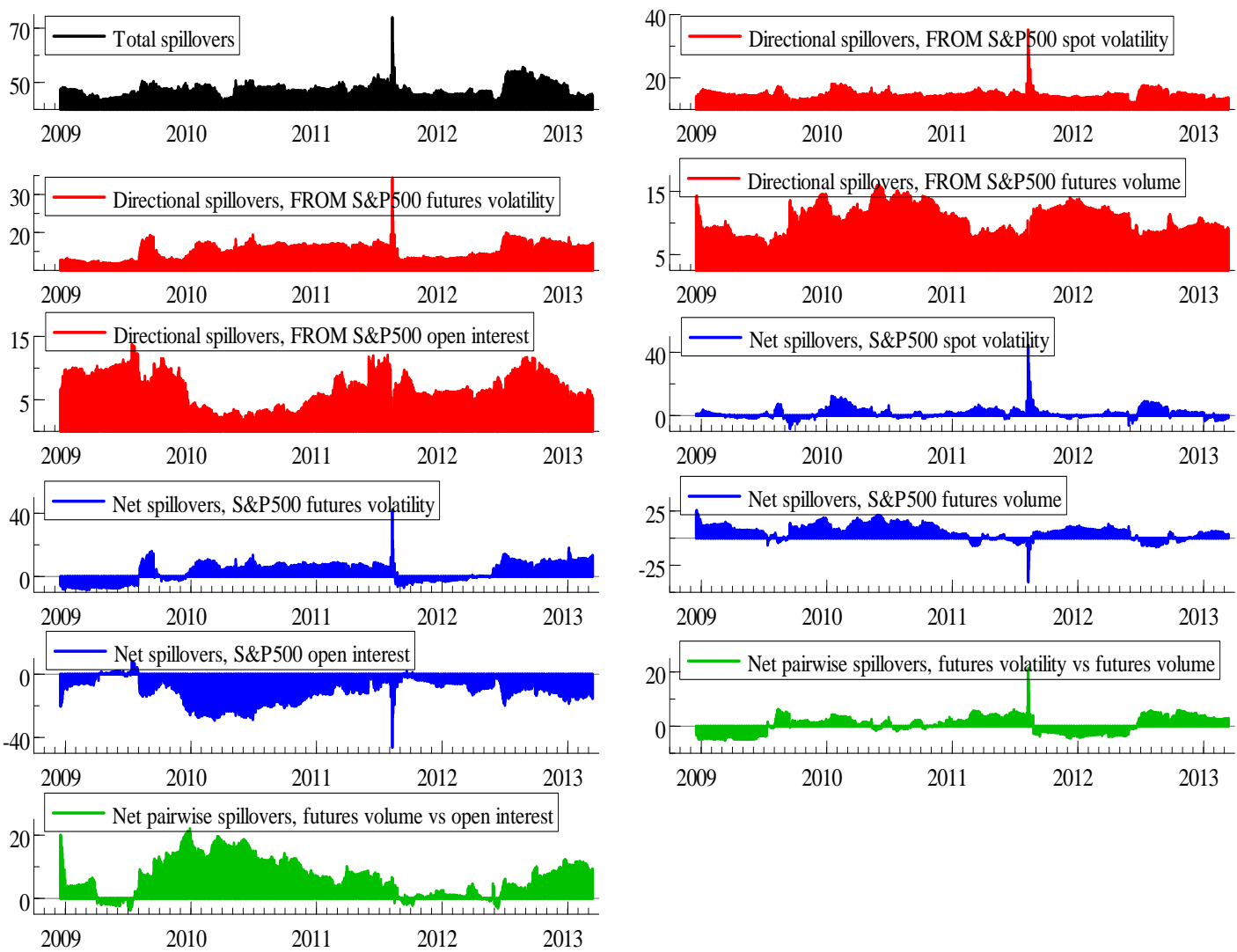

Note: Dynamic total, directional, net spillover and net pairwise spillover indices are depicted in this figure. For instance, positive (negative) values of the S\&P 500 futures volume net spillover indicate that the S\&P 500 futures volume is a net transmitter (receiver) whereas the FTSE 100 futures and spot volatility, and the open interest are collectively net receivers (transmitters) of spillovers. The underlying variance decomposition is based upon a bivariate VAR of order 5, which is dictated by the Schwarz Bayesian Information Criterion. Spot and futures volatilities are measured by the conditional variances that are obtained from the DCC-GARCH model of Engle (2002). Spillover indices are estimated using 200-day rolling windows. Spillover indices, given by Equations 4-8, are calculated from variance decompositions based on 10-stepahead forecasts. We use daily data for the period 02/25/2008 - 04/23/2013 (a total of 1247 observations). 


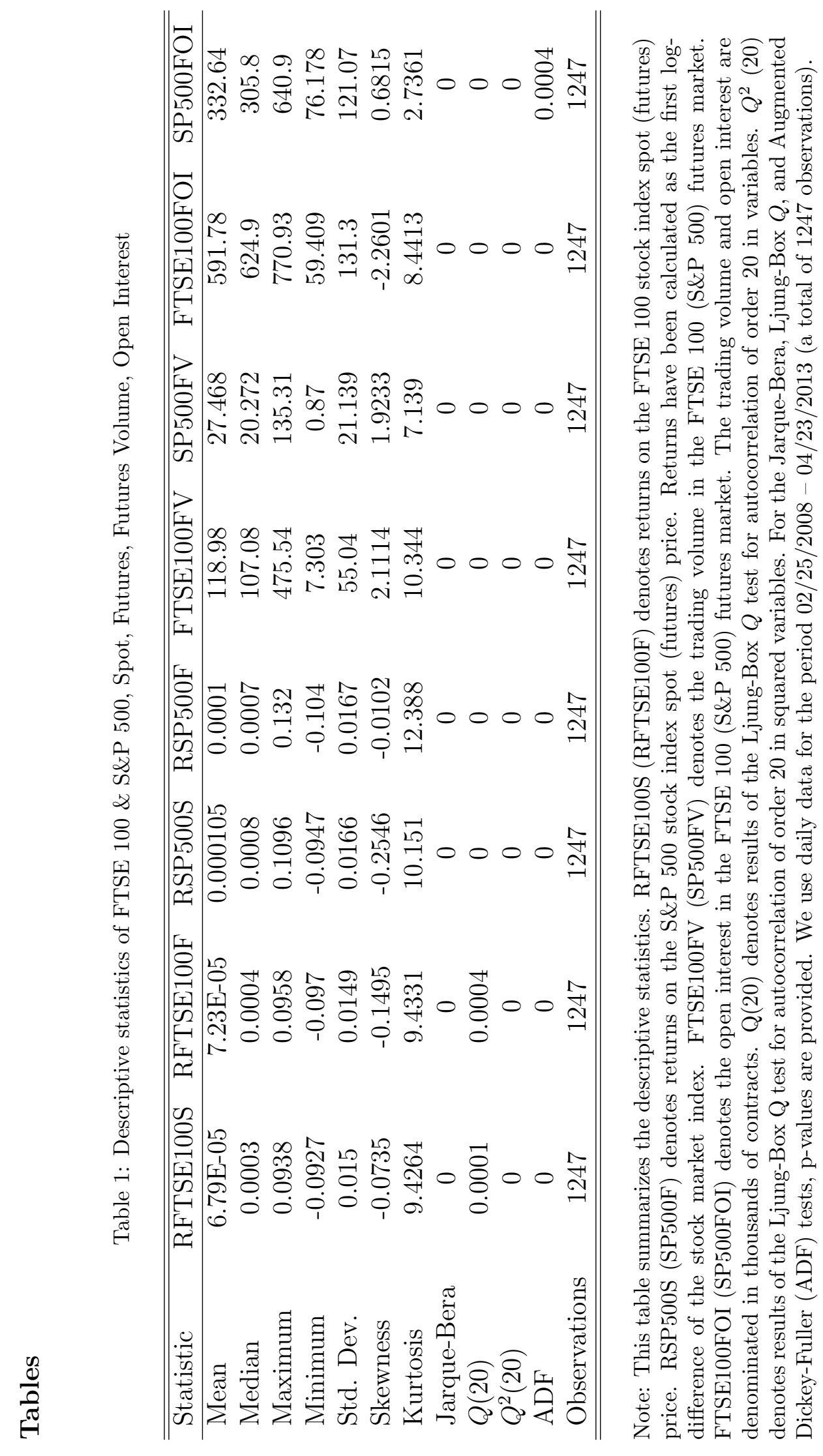


Table 2: Spillover table - FTSE 100 Spot and Futures Volatility

\begin{tabular}{lccc}
\hline \hline & \multicolumn{3}{c}{ From $(j)$} \\
\cline { 2 - 4 } To $(i)$ & CVFTSE100S & CVFTSE100F & $\begin{array}{c}\text { Contr. } \\
\text { from Others }\end{array}$ \\
\hline CVFTSE100S & 51.6 & 48.4 & 48.4 \\
CVFTSE100F & 50.7 & 49.3 & 50.7 \\
\hline Contr. to others & 50.7 & 48.4 & Total Spillover \\
Contr. incl. own & 102.3 & 98.7 & Index $=49.6 \%$ \\
\hline \hline
\end{tabular}

Note: Total, directional and pairwise spillovers are summarized in this table. CVFTSE100S (CVFTSE100F) denotes the volatility of the FTSE 100 stock index spot (futures) returns. For instance, the value in the first row and the second column (48.4\%) indicates the magnitude of the pairwise spillover from the FTSE 100 futures volatility to the FTSE 100 spot volatility. The underlying variance decomposition is based upon a bivariate VAR of order 5, which is dictated by the Schwarz Bayesian Information Criterion. Spot and futures volatilities are measured by the conditional variances that are obtained from the DCC-GARCH model of Engle (2002). Spillover indices, given by Equations 4-8 are calculated from variance decompositions based on 10-step-ahead forecasts. We use daily data for the period 02/25/2008 - 04/23/2013 (a total of 1247 observations) 
Table 3: Spillover table - S\&P 500 Spot and Futures Volatility

\begin{tabular}{lccc}
\hline & \multicolumn{3}{c}{ From $(j)$} \\
\cline { 2 - 4 } To $(i)$ & $C V S P 500 S$ & $C V S P 500 F$ & Contr. \\
& from Others \\
\hline$C V S P 500 S$ & 52.7 & 47.3 & 47.3 \\
$C V S P 500 F$ & 48.8 & 51.2 & 48.8 \\
\hline Contr. to others & 48.8 & 47.3 & Total Spillover \\
Contr. incl. own & 101.5 & 98.5 & Index $=48.1 \%$ \\
\hline \hline
\end{tabular}

Note: Total, directional and pairwise spillovers are summarized in this table. CVSP500S (CVSP500F) denotes the volatility of the S\&P 500 stock index spot (futures) returns. For instance, the value in the first row and the second column (47.3\%) indicates the magnitude of the pairwise spillover from the S\&P 500 futures volatility to the S\&P 500 spot volatility. The underlying variance decomposition is based upon a bivariate VAR of order 12, which is dictated by the Schwarz Bayesian Information Criterion. Spot and futures volatilities are measured by the conditional variances that are obtained from the DCC-GARCH model of Engle (2002). Spillover indices, given by Equations 4-8, are calculated from variance decompositions based on 10-step-ahead forecasts. We use daily data for the period $02 / 25 / 2008-04 / 23 / 2013$ (a total of 1247 observations).

Table 4: Spillover table - FTSE 100 \& S\&P 500 Spot and Futures Volatility

\begin{tabular}{lccccc}
\hline \hline & \multicolumn{5}{c}{ From $(j)$} \\
\cline { 2 - 6 } To $(i)$ & CVFTSE100S & CVFTSE100F & CV SP500S & CVSP500F & $\begin{array}{c}\text { Contr. } \\
\text { from Others }\end{array}$ \\
\hline CVFTSE100S & 33.0 & 30.3 & 18.2 & 18.5 & 67.0 \\
CVFTSE100F & 31.8 & 30.6 & 18.5 & 19.0 & 69.3 \\
CVSP500S & 15.5 & 13.8 & 37.3 & 33.4 & 62.7 \\
CVSP500F & 17.9 & 16.5 & 31.5 & 34.1 & 65.9 \\
\hline Contr. to others & 65.2 & 60.6 & 68.2 & 70.9 & Total Spillover \\
Contr. incl. own & 98.2 & 91.2 & 105.5 & 105.0 & Index $=66.2 \%$ \\
\hline \hline
\end{tabular}

Note: Total, directional and pairwise spillovers are summarized in this table. CVFTSE100S (CVFTSE100F) denotes the volatility of the FTSE 100 stock index spot (futures) returns. CVSP500S (CVSP500F) denotes the volatility of the S\&P 500 stock index spot (futures) returns. For instance, the value in the fourth row and the second column (16.5\%) indicates the magnitude of the pairwise spillover from the S\&P 500 futures volatility to the FTSE 100 futures volatility. The underlying variance decomposition is based upon a fourvariate VAR of order 12, which is dictated by the Schwarz Bayesian Information Criterion. Spot and futures volatilities are measured by the conditional variances that are obtained from the DCC-GARCH model of Engle (2002). Spillover indices, given by Equations 4-8, are calculated from variance decompositions based on 10-step-ahead forecasts. We use daily data for the period 02/25/2008 - 04/23/2013 (a total of 1247 observations). 
Table 5: Spillover table - FTSE 100 Spot and Futures volatility, Futures Volume \& Open Interest

\begin{tabular}{lccccc}
\hline \hline & \multicolumn{4}{c}{ From $(j)$} \\
\cline { 2 - 6 } To $(i)$ & CVFTSE100S & CVFTSE100F & FTSE100FV & FTSE100FOI & $\begin{array}{c}\text { Contr. } \\
\text { from Others }\end{array}$ \\
\hline CVFTSE100S & 44.1 & 40.9 & 9.6 & 5.3 & 55.8 \\
CVFTSE100F & 43.5 & 42.1 & 8.9 & 5.6 & 58.0 \\
FTSE100FV & 2.0 & 1.7 & 85.5 & 10.8 & 14.5 \\
FTSE100FOI & 1.2 & 1.5 & 33.4 & 63.9 & 36.1 \\
\hline Contr. to others & 46.7 & 44.0 & 51.9 & 21.7 & Total Spillover \\
Contr. incl. own & 90.8 & 86.1 & 137.4 & 85.6 & Index $=41.1 \%$ \\
\hline \hline
\end{tabular}

Note: Total, directional and pairwise spillovers are summarized in this table. CVFTSE100S (CVFTSE100F) denotes the volatility of the FTSE 100 stock index spot (futures) returns. FTSE100FV denotes the seasonally adjusted series, $\gamma_{t}$, of trading volume in the FTSE 100 futures market based on Equation (9). FTSE100FOI denotes the seasonally adjusted series, $\delta_{t}$, of open interest in the FTSE 100 futures market based on Equation (10) For instance, the value in the fourth row and the third column (33.4\%) indicates the magnitude of the pairwise spillover from the FTSE 100 futures trading volume to the FTSE 100 futures open interest. The underlying variance decomposition is based upon a four-variate VAR of order 5 , which is dictated by the Schwarz Bayesian Information Criterion. Spot and futures volatilities are measured by the conditional variances that are obtained from the DCC-GARCH model of Engle (2002). Spillover indices, given by Equations 4-8, are calculated from variance decompositions based on 10-step-ahead forecasts. We use daily data for the period 02/25/2008 - 04/23/2013 (a total of 1247 observations).

Table 6: Spillover table - S\&P 500 Spot and Futures volatility. Futures Volume \& Open Interest

\begin{tabular}{lccccc}
\hline \hline & \multicolumn{5}{c}{ From $(j)$} \\
\cline { 2 - 6 } To $(i)$ & $C V S P 500 S$ & $C V S P 500 F$ & $S P 500 F V$ & SP500OFOI & $\begin{array}{c}\text { Contr. } \\
\text { from Others }\end{array}$ \\
\hline CVSP500S & 47.8 & 42.7 & 6.0 & 3.5 & 52.2 \\
CV SP 500F & 44.7 & 47.0 & 5.3 & 3.0 & 53.0 \\
SP500FV & 1.7 & 0.7 & 85.5 & 12.0 & 14.4 \\
SP500FOI & 6.5 & 4.7 & 26.9 & 62.0 & 38.1 \\
\hline Contr. to others & 52.9 & 48.1 & 38.2 & 18.5 & Total Spillover \\
Contr. incl. own & 100.7 & 95.1 & 123.7 & 80.5 & Index $=39.4 \%$ \\
\hline \hline
\end{tabular}

Note: Total, directional and pairwise spillovers are summarized in this table. CVSP500S (CVSP500F) denotes the volatility of the S\&P 500 stock index spot (futures) returns. SP500FV denotes the seasonally adjusted series, $\zeta_{t}$, of trading volume in the S\&P 500 futures market based on Equation (11). SP500FOI denotes the seasonally adjusted series, $\theta_{t}$, of open interest in the S\&P 500 futures market based on Equation (12). For instance, the value in the fourth row and the third column $(26.9 \%)$ indicates the magnitude of the pairwise spillover from the S\&P 500 futures trading volume to the S\&P 500 futures open interest. The underlying variance decomposition is based upon a four-variate VAR of order 6 , which is dictated by the Schwarz Bayesian Information Criterion. Spot and futures volatilities are measured by the conditional variances that are obtained from the DCC-GARCH model of Engle (2002). Spillover indices, given by Equations 4-8, are calculated from variance decompositions based on 10-step-ahead forecasts. We use daily data for the period 02/25/2008 - 04/23/2013 (a total of 1247 observations). 


\section{Appendix}

Table 1 presents the descriptive statistics for returns, trading volumes and open interest. On average, daily returns are positive and higher for the S\&P 500 stock index. In the S\&P 500 (FTSE 100) stock index futures market, there are on average 27.5 (119) thousand daily trade contracts. The average daily open interests in the S\&P 500 and FTSE 100 stock index futures markets are 333 and 592 thousand contracts, respectively. The trading volume and open interest show higher volatility for the FTSE 100 stock index futures market. The negative values for skewness of returns indicate that the sampling distributions are skewed to the left, making the occurrence of large negative values more likely than large positive values. Returns from the S\&P 500 stock index futures (spot) market are relatively less (more) skewed than returns from the FTSE 100 stock index futures (spot) market. The volumes of trading are positively skewed, whereas the open interest in the FTSE 100 (S\&P 500) stock index futures market is positively (negatively) skewed. The values of excess kurtosis are positive, indicating that the sampling distributions are leptokurtic or peaked.

Unit root tests based the Augmented Dickey-Fuller (ADF) procedure were conducted and suggest that the series are stationary. As a result, spot and futures returns, the trading volume and the open interest are used in the subsequent analyses.

The Ljung-Box Q test shows evidence of serial correlation up to order 20 in the variables and variables squared. This motivates using a generalized autoregressive conditional heteroscedasticity $(\mathrm{GARCH})$ approach to model the observed volatility clustering. Evidence of conditional volatility in futures market is reported in the literature (for survey, see ?). ? use the dynamic conditional correlation (DCC) based GARCH model to study the volatility asymmetries in the FTSE 100 stock index spot and futures markets.

Figure 1 depicts variation over time in the FTSE 100 stock index spot and futures prices (Panel A), and spot and futures continuously compounded returns (Panel B). Panel A shows that the stock and futures prices were generally decreasing in 2008, following the sub-prime mortgage crisis in the US and the global financial crisis, until they reached a trough in the first quarter of 2009. They started to recover since then with occasional reversals. As expected, the two series showed very similar variation over time. Panel B shows that the stock and futures returns became volatile in the bearish stock market. Spot and futures return volatility started to decrease in 2009. Figure 2 depicts variation over time in the S\&P 500 stock index spot and futures prices (Panel A), and spot and futures continuously compounded returns (Panel B). As for the case of the FTSE 100 stock market index, the S\&P 500 stock index spot and futures prices were decreasing until the first quarter of 2009, and they started to recover since then (Panel A). In the bearish stock market stance spot and futures returns also saw increased variability (Panel B).

Figure 3 depicts variation over time in the volume of trading in FTSE 100 stock index futures market (Panel A), and the open interest (Panel B). Panel A shows that the volume of trading has undergone significant variation overtime. Graphical inspection allows identifying seasonal effects that are caused by increased trade activity with a futures contract approaching its expiration in March, June, September and December. Trade activity particularly intensifies in the last days of a contracts maturity. Fluctuations of the volume of 
trading tend to revert to a gradually declining mean. The largest increase in the volume of trading occurred around the beginning of the global financial crisis in October 2008.

The open interest also shows significant seasonal effects. Unlike with the volume of trading, the open interest decreases the nearer is a futures contract to its expiration, as traders close their positions. When the futures contract expires, traders start opening new positions in the next near contract. As with the volume of trading, the open interest increased abruptly in the beginning of the global financial crisis and has permanently remained higher than its pre-crisis level. Given the above observations, the FTSE 100 futures volume and open interest series are adjusted for the systematic seasonal effects using the following respective regression equations

$$
\begin{gathered}
\text { FTSE100FV } V_{t}=\alpha_{0}+\alpha_{1} D_{M A R t}+\alpha_{2} D_{J U N t}+\alpha_{3} D_{S E P t}+\alpha_{4} D_{D E C t}+\gamma_{t} \\
F T S E 100 F O I_{t}=\alpha_{0}+\alpha_{1} D_{M A R t}+\alpha_{2} D_{J U N t}+\alpha_{3} D_{S E P t}+\alpha_{4} D_{D E C t}+\delta_{t},
\end{gathered}
$$

where $D_{\text {MARt }}, D_{J U N t}, D_{S E P t}$ and $D_{D E C t}$ are the dummy variables that equal to one if the month is March, June, September and December, respectively, and zero otherwise, $\alpha_{i}$ are the parameters to be estimated, and $\gamma_{t}$ and $\delta_{t}$ are the error terms. The residuals, $\gamma_{t}$ and $\delta_{t}$, from Equations 9 and 10 above are the seasonally adjusted FTSE 100 futures volume and open interest series. Throughout the remainder of the paper, the analysis is based on the seasonally adjusted returns series, $\gamma_{t}$ and $\delta_{t}$.

Figure 4 depicts variation over time in the volume of trading in S\&P 500 stock index futures market (Panel A), and the open interest (Panel B). The volume of trading and the open interest show a different pattern from that depicted in Figure 3. First of all, both the volume of trading and the open interest show a clear tendency to decrease. Second, the observed increase in the open interest in the beginning of the global financial crisis is transitory. Therefore, the S\&P 500 futures volume and open interest series are adjusted for the systematic seasonal effects and the declining trend using the following respective regression equations

$$
\begin{gathered}
S \& P 500 F V_{t}=\alpha_{0}+\alpha_{1} D_{M A R t}+\alpha_{2} D_{J U N t}+\alpha_{3} D_{S E P t}+\alpha_{4} D_{D E C t}+\alpha_{5} \text { Trend }+\zeta_{t} \\
S \& P 500 F O I_{t}=\alpha_{0}+\alpha_{1} D_{M A R t}+\alpha_{2} D_{J U N t}+\alpha_{3} D_{S E P t}+\alpha_{4} D_{D E C t}+\alpha_{5} \text { Trend }+\theta_{t},
\end{gathered}
$$

where $D_{\text {MARt }}, D_{J U N t}, D_{S E P t}$ and $D_{D E C t}$ are defined similarly as the ones above, Trend is a linear time trend, $\alpha_{i}$ are the parameters to be estimated, and $\zeta_{t}$ and $\theta_{t}$ are the error terms. ${ }^{13}$ The residuals, $\zeta_{t}$ and $\theta_{t}$, from Equations 11 and 12 above are the seasonally adjusted S\&P 500 futures volume and open interest series. Throughout the remainder of the paper, the analysis is based on the seasonally adjusted returns series, $\zeta_{t}$ and $\theta_{t}$.

\footnotetext{
${ }^{13}$ We have also explored the robustness of our results with the use of alternative seasonal adjustment techniques. In particular, we have used: (i) dummy variables for the day of contract expiry instead of the aforementioned dummies, (ii) monthly moving average technique and (iii) month-on-month differences techniques, so as to remove the seasonality observed in the futures volume and the open interest data series. The results based on these alternative seasonal adjustment techniques are very similar to those presented in this study. For the sake of brevity, therefore, the results based on the aforementioned techniques are not presented, however, are available from the authors upon request.
} 